\title{
PHYLOGENETIC RELATIONSHIPS AND BIOGEOGRAPHY OF THE GROUNDWATER-DWELLING AMPHIPOD GENUS PSEUDONIPHARGUS (CRUSTACEA), WITH EMPHASIS ON THE IBERIAN SPECIES
}

\author{
by \\ JOS NOTENBOOM \\ Institute of Taxonomic Zoology, University of Amsterdam, P.O. Box 4766, 1009 AT Amsterdam, \\ The Netherlands
}

\begin{abstract}
Numerical phylogenetic methods are applied in order to arrive at synapomorphic similarities between species of the stygobiont amphipod genus Pseudoniphargus. Character polarity is assessed by comparison with the relevant outgroups Parapseudoniphargus and Allomelita, within a cluster of presumedly interrelated genera of Hadzioidea.

The degree of morphological differentiation of Pseudoniphargus is low and the available potential apomorphies are insufficient to resolve phylogenetic relationships to the species level. The inconsistency in the data is high, which may be a result of an underlying peripatric speciation model, difficulties in discriminating mutual exclusive and homologous character states, and a high probability of independent character evolution. Problems of phylogeny reconstruction at low taxonomic levels are universal. Accidental problems in the case of a stygobiont group are caused by troglomorphism, structural reduction, and senescent morphology.

The results of the study lead to the recognition of four well-corroborated monophyletic groups; three consist of sister species only. Remaining taxa are ungrouped or belong to groups which do not emerge after all numerical approaches. The monophyletic groups of Pseudoniphargus are for the greater part geographically coherent and confined either to the Cantabrian Mountains, or to the Lusitanian-Atlantic region, or to the Betic Cordillera. The possible origin of Pseudoniphargus from a thalassostygobiont progenitor which arose in the eastern Atlantic part of the shallow Tethys sea is discussed.
\end{abstract}

\section{RESUMEN}

Se han aplicado métodos filogenéticos numéricos con el fin de obtener similitudes sinapomórficas entre especies de Pseudoniphargus, género de anfípodos estigobiontes. La polaridad de los caracteres ha sido determinada por comparación con Parapseudoniphargus y Allomelita, grupos externos especialmente significativos, en el contexto de un cluster de géneros de Hadzioidea presumiblemente interrelacionados.
El grado de diferenciación morfológica de Pseudoniphargus es bajo y los potenciales apomorfismos disponibles son insuficientes para resolver las relaciones filogenéticas a nivel de especie. Ello puede ser atribuible a un modelo de especiación peripátrica subyacente, a problemas de discriminación de estados de carácter mutualmente excluyentes y homólogos, y a una probabilidad alta de evolución independiente de caracteres. Los problemas que plantea la reconstrucción filogenética de niveles taxonómicos bajos son universales. En el caso de un grupo estigobionte, el troglomorfismo, la reducción estructural y la morfología senescente provocan problemas peculiares.

Los resultados del estudio conducen al reconocimiento de cuatro grupos monofiléticos bien definidos, tres de los cuales consisten únicamente en especies hermanas. Los taxones restantes quedan sin agrupar o pertenecen a grupos que no se han podido evidenciar a pesar de todas las aproximaciones numéricas. Los grupos monofiléticos de Pseudoniphargus son, en su mayor parte, geográficamente coherentes y se circunscriben a los Montes Cantábricos, o área Lusitano-Atlántica o Cordillera Bética. Por último, se discute el posible origen de los Pseudoniphargus a partir de un ancestro talasoestigobionte originario de aguas someras del área oriental atlántica del mar de Tethys.

\section{CONTENTS}

1. Introduction................................. 160

2. Material and methods .......................... 161

3. Characteristics of Pseudoniphargus................. 163

3.1 Comprehensive diagnosis................. 163

3.2 Distribution and biology ................. 165

4. The phylogenetic position of Pseudoniphargus .... 167

4.1 Classificatory problems .................... 167

$\begin{array}{lll}4.2 \text { Delimitation of presumedly related taxa.... } & 167\end{array}$

4.3 Numerical phylogenetic analysis............ 169

5. Phylogenetic relationships within Pseudoniphargus 174

5.1 Character analysis ....................... 174

5.2 Explanatory notes to the characters ........ 177

5.3 Numerical phylogenetic analysis............ 182

5.4 Diagnosis of monophyletic groups of Pseudoniphargus ............................... 187 
6. Discussion of phylogenetic results ............. 188

6.1 Character incompatibility and unresolved relationships....

6.2 Hypogean features as complicating factors in phylogeny reconstruction .................

6.3 Phylogenetic methodology ....

7. Origin of Pseudoniphargus and biogeography .....

Acknowledgements ..............................

References.

polychotomous branching were fairly neglected in these studies. Furthermore, the groups under consideration are rarely defined on the basis of shared derived characters (synapomorphies). Modern biogeography is based on phylogenetic hypotheses and inferences of the history of a group from that phylogeny (Wiley, 1981), both distributional and paleogeographic data being used. Biogeographic studies of stygobiont amphipods are, however, often based on weakly developed phylogenetic hypotheses.

The purpose of the present study is to explore

Amphipods have very successfully invaded a wide range of subterranean aquatic habitats, from marine to continental hypogean waters, and from interstitia of microporous sediments to large karstic basins. Those amphipods that are obligate dwellers of groundwater habitats (stygobionts) constitute a taxonomically highly diverse group, with presumed multiple origins from different ancestral stocks. They are worldwide in distribution, and known from tropical, subtropical, temperate and exceptionally also from cold regions, in general showing a high degree of endemism. Dispersal abilities of the stygofauna are limited, owing to their intrinsic properties and stratigraphic barriers.

Many zoogeographic studies so far dedicated to the intriguing distribution patterns of stygobiont amphipods focus on the greater Caribbean and peri-Mediterranean regions. Historical events, such as continental drift, marine regressions, and tectonic uplift are considered to have had an important effect on the present distribution patterns. Developments in vicariance biogeography and area cladistics have had a noticeable influence on recently published zoogeographical studies dealing with groups of stygobiont amphipods (Stock, 1980a; Holsinger, 1986; Stock \& Rondé-Broekhuizen, 1986; Boutin \& Coineau, 1988; Boutin \& Messouli, 1988). However, the cladograms presented in these papers seem to be based on a global concept concerning character state transformation rather than on a phylogenetic analysis. Comparisons with closely related outgroups, homology of character states, and

the phylogenetic relationships of the genus Pseudoniphargus, with emphasis on the Iberian species, by using phylogenetic numerical techniques. Pseudoniphargus is an important subject in the literature on the biogeography of stygobiont animals. The relationship between hypothesized cladogenetic events within the genus and the paleogeography of the distributional areas of the species was used by Stock (1980a) to exemplify the "Regression Model'. This model, as originally formulated by Stock (1977), gives explanations for the distribution, in brackish and fresh continental, but mainly insular, groundwaters, of stygobionts from direct marine origin. In the literature devoted to the biogeography of stygobiont animals, the "Regression Model" has frequently been discussed (see e.g., Danielopol, 1980; Rouch \& Danielopol, 1987). During the past few years, many new species of Pseudoniphargus have been described from Atlantic and western periMediterranean regions, especially from the Iberian Peninsula (Notenboom, 1986, 1987a, b; Stock et al., 1986; Stock, 1988; Boutin \& Coineau, 1988). Through these new findings it became evident that the distribution pattern of characters and the relationships among the taxa are much more complex than was thought before. For future discussions on the "Regression Model" and the evolution of stygobiont animals, it was deemed desirable to submit the genus to a phylogenetic study.

An important obstacle in phylogenetic studies of amphipods at lower taxonomic levels is the highly debated classification into families and superfamilies, above all that of the 
suborder Gammaridea. Probably none of the actually proposed classifications reflects the natural relationships and very little is known about the synapomorphic similarity between taxa. The external morphological features currently used in the systematics of Gammaridea probably are inadequate to provide a natural classification of this group. Attempts to explore new character sets have been made by Lincoln \& Hurley (1981) and Lincoln (1984): calceoli; by Bousfield (1985): reproduction and mating strategies; and by Halcrow \& Bousfield (1987): surface microstructures. These developments, in combination with the application of phylogenetic systematics including numerical approaches, will probably yield promising classifications of higher natural taxa within the Gammaridea. Since such a classification is not yet within reach, the initial assumption concerning the position of Pseudoniphargus within one of the Gammaridea superfamily groups is of necessity based on phenetic similarity rather than on a quest for synapomorphies.

Computer-assisted phylogenetic techniques are applied because the data show a low internal consistency. Two important principles underly this study: first, the phylogenetic-systematic criterion that monophyletic groups can only be defined on the basis of synapomorphies; and second, the principle of minimizing either the number of evolutionary steps (parsimony method) or the number of incompatible characters (compatibility method). For an introduction to these methods, the reader is referred to Felsenstein (1982). The parsimony principle has no biological basis, except that nature is not completely chaotic and seems to be ordered to at least some extent (Von Vaupel Klein, 1987). The criterion is discussed at length in the modern systematic literature (e.g., Johnson, 1982; Kluge, 1984; Sober, 1985). Without entering into a discussion about the value of the (quantitative) parsimony criterion in phylogenetic studies, it is accepted because it has a logical methodological basis and is applied for lack of supplemental (qualitative) biological evidence.
The intention of this paper is to find monophyletic groups within Pseudoniphargus. The methodology used is repeatable and thus the result testable. It will be shown that the data are inadequate to provide a single solution. Tree topologies of equally parsimonious solutions are compared and conclusions about affinities will be drawn for a rather limited number of taxa only. The method of outgroup comparison is used to assess apomorphous character states, and to that end an outgroup hypothesis of Pseudoniphargus was developed. Foibles in the data set leading to unresolved phylogenetic relationships between many of the taxa are discussed. The present study exemplifies the problems encountered when criteria of phylogenetic systematics, in combination with numerical techniques, are applied to a group of stygobiont amphipods.

\section{MATERIAL AND METHODS}

The phylogenetic analysis performed in this paper consists of two parts: the first (outgroup analysis) provides a hypothesis about the relationships of Pseudoniphargus within the Hadzioidea, in order to determine the outgroups relevant to the phylogenetic analysis within Pseudoniphargus, and the second (ingroup analysis) results in assumptions about synapomorphic similarities between species of Pseudoniphargus (recognition of monophyletic groups). Outgroup comparison (Watrous \& Wheeler, 1981) is applied in the ingroup analysis to assess character polarity. Rules as given by Maddison et al. (1984) have been applied to deal with variation among the outgroups. The data resulting from character analysis of both the outgroup and the ingroup are analysed with the PHYLIP versions 2.9 and 3.0 packages of numerical phylogenetic computer programs (Felsenstein, 1987).

\section{Material}

The outgroup analysis is almost completely based on characters and character distributions supplied by the literature and augmented with a personal study of 
Allomelita Stock, 1984 and Parapseudoniphargus Notenboom, 1988. A survey of the literature resulted in a list of diagnostic, qualitative features of taxa presumably closely related to Pseudoniphargus. Indistinctly and inconsistently described characters among the taxa have been eliminated. In a few cases, however, unknown or insufficiently described character states are coded in the data matrix with a question mark, or with an indication of the two states that probably occur.

The ingroup analysis includes all presently known, identified Iberian material of Pseudoniphargus (see the checklist in Notenboom, 1987b), with the exception of $P$. longispinum Stock, 1980 (see remark in Notenboom, 1987b: 201). The character analysis of Iberian species has been performed on the basis of recent taxonomic studies dealing with this material (Notenboom, 1986, 1987a, b). From outside Iberia the species $P$. grandimanus Stock et al., 1986 and $P$. carpalis Stock et al., 1986, from Bermuda, $P$. brevipedunculatus Stock, 1980, from the Azores, and $P$. adriaticus S. Karaman, 1955, from the Mediterranean basin, have been incorporated. Data on non-Iberian species have been borrowed from Karaman (1978a, 1982), Stock (1980a), and Stock et al. (1986), augmented with personal observations on the type-specimens of $P$. grandimanus, $P$. carpalis, and $P$. brevipedunculatus; and through an additional study of material, identified as $P$. adriaticus, originating from Le Petit Gaou and Banyuls (France) and Mallorca (Balearic Islands).

The two species described from Algeria, viz., $P$. africanus Chevreux, 1901 and $P$. macrotelsonis Stock, 1980, are excluded from the analysis. Recent investigations have shown that these two "species" are part of a large assemblage of different forms of Pseudoniphargus which is widely distributed in northern Algeria (Notenboom \& De Winter, 1986; unpublished). This material awaits a complete taxonomic research and it does not appear to be meaningful to include only a part of this fauna in the present study. Recently described Pseudoniphargus species from Morocco (Boutin Coineau, 1988) and the Canary Islands (Stock, 1988) could not be incorporated.

Morphological studies of preserved specimens of Pseudoniphargus, Parapseudoniphargus and Allomelita were made by dissecting all appendages of both sexes. The appendages were mounted in Faure's solution and observed with a Leitz Dialux 20 EB microscope. Measurements of qualitative characters were made by means of a camera lucida drawing tube and a curvimeter. States of continuous quantitative characters were determined by gap coding, means of measurements on species were separated by one or by more standard deviating units (Mickevich * Johnson, 1976; Archie, 1985). Depending on the number of specimens available per species, at least two males and two females, but mostly more individuals, have been studied in detail. Additional observations of undissected specimens have been made by means of a Wild M3 dissection microscope. Unique characters not found in other species of the genus or in closely related outgroups are considered to be autapomorphies.
Equivocal ancestral states and polymorphic characters are coded with a question mark according to the recommendations of Pimentel \& Riggins (1987).

All the material studied is stored in the Amphipoda collection of the Zoölogisch Museum, Amsterdam.

\section{Numerical phylogenetic methods}

Data matrices of outgroup and ingroup analyses, with the exclusion of autapomorphous characters, were analysed with the MIX portion of PHYLIP on an IBM PC/XT compatible. Cladograms were construed under the Wagner (Eck \& Dayhoff, 1966; Kluge \& Farris, 1969) and Camin-Sokal (Camin \& Sokal, 1965) parsimony options. Under the Camin-Sokal criterion, changes in a particular character from the plesiomorphous condition to an apomorphous one are much more probable than the reverse, while under the Wagner criterion both changes are equally probable. The program attempts to minimize the number of steps (changes in character state) in order to explain the pattern of character state distribution among the taxa (parsimony). An additional stage, the global optimization routine, in the search for the best cladogram is added in all runs made with the MIX program (see PHYLIP documentation; Felsenstein, 1987). According to the recommendations of Felsenstein, 10 runs on shuffled data were made. This gives a better chance to find the most parsimonious cladogram(s) and, further, cnables a comparison between alternative cladogram topologies. There appeared to be no qualitative biological evidence to weigh characters. Weighing has only been performed by making additional runs with MIX in the ingroup analysis, compatible characters being given a double weight.

Likewise, most parsimonious cladograms found under similar premises were evaluated by comparing their topologies and the distribution of synapomorphies. Consensus cladograms were constructed on the basis of PHYLIP CONSENSE. These cladograms include only the monophyletic groups and their synapomorphies about which there is a strict consensus in all equally most parsimonious solutions. Underlined synapomorphies are uniquely derived characters. Non-underlined characters are not uniquely derived weak autapomorphies or synapomorphies.

Compatibility analysis (Le Quesne, 1969) was performed by using the threshold method carried out by PHYLIP MIX. The use of the treshold function provides the possibility to handle missing data as we have in this case. Compatibility methods search for the largest collection(s) of mutually compatible characters (the largest clique(s)) among the data and select those tree(s) which have the lowest number of incompatible characters. See Meacham \& Estabrook (1985) for a review of compatibility analysis, and Felsenstein (1981) for an explanation of the threshold function and for its possible application as a compatibility method. 


\section{Motivation of the selected method}

In an initial stage of this study the Pseudoniphargus data were analysed with the following numerical-phylogenetic computer programs: Tree Tools (Ellis, 1987), CAFCA (Zandee, 1987), and PHYLIP. The underlying philosophy was to make the result as much as possible methodindependent. However, it has become evident that the internal conflict in the data sets used is substantial, and that an unambiguous phylogenetic solution, or a solution about which there is a good deal of consensus, could not be attained. This problem overshadows the differences in the results obtained by methods based on different algorithms and theoretical assumptions. Apparently, it is rather inane to discuss the, often very subtle, differences found between the output of different methods applied to our data, because this contributes but very little to the insight into the phylogenetic relationships between species of Pseudoniphargus.

The package PHYLIP has been chosen for a final analysis because its portions are flexible and a choice can be made between different algorithms that start from welldefined biological assumptions. Moreover, the methodological and theoretical principles on which the programs of the package rest are well described in an extensive bibliography (see the PHYLIP documentation and literature references, given by Felsenstein, 1987).

\section{CHARACTERISTICS OF PSEUDONIPHARGUS}

\subsection{Comprehensive diagnosis}

\section{Pseudoniphargus Chevreux, 1901}

Chevreux, 1901: 211; G. Karaman, 1978a: 241, 1982: 354 \& 356; Stock, 1980a: 116; Barnard \& Barnard, 1983: 685-686 (partim Chevreux); Notenboom, 1986: 84, 1987a: 93 .

Length (excluding antennae and 3rd uropod) between about 3.5 and $11.5 \mathrm{~mm}$ (of $P$. incantatus Notenboom, 1986 and $P$. grandis Notenboom, 1987, respectively), but in most species ranging between 4.0 and $7.0 \mathrm{~mm}$. Eyes totally lacking. Body unpigmented, elongate, and smooth with the exception of some small setules on posterior dorsal margin of metasome, and a pair of dorsolateral setules on urosomites. Rostrum lacking, antennal sinus shallow. Antenna 1 longer than antenna 2. Pedunculus of both antennae subsimilar in length, not elongate. Accessory flagellum short, 2-segmented with minute terminal segment. Distal segments of antenna 1 with a single, cudgelshaped aesthetasc on each segment in both sexes; aesthetascs absent on antenna 2.

Upper lip entire, apically rounded. Lower lip wingshaped, inner lobes prominent. Corpus mandibulae asymmetrical. Lacinia mobilis: left 4-dentate, right bi-lobed and multidentate. Molar triturative with a single molar seta on either side. Palp 3-segmented; segment 1 short, unarmed; segment 2 with distoventral setae; segment 3 falcate, well developed and bearing A, B, D, and E-setae, its ventral margin with a bend separating an unarmed proximal part from an armed (D-setae) distal part. Maxilla 1: outer lobe with 7 (sometimes 6 or 8 ) strong, and smooth or denticulate spines. Inner lobe with 2 or 3 distal setae. Palp 2-segmented, segment 1 short and unarmed, segment 2 with fine marginal setules and 4-10 distal clements. Maxilla 2: inner lobe with a distal row of setae only; outer lobe with 2 separate distal groups of setae, medial group consisting of a row of setae along its inner and outer sides, the lateral group of longer setae with smooth shaft well demarcated from the feathered distal part. Maxilliped: inner lobe short with 4-8 distal elements; outer lobe well developed, exceeding half the length of palp segment 2, medial margin provided with blade-like spines of distally increasing length. Palp 4-segmented; segment 1 short; segment 2 the longest with irregularly implanted setae on medial surface; segment 3 short, distally widened and covered with fine setules on the distolateral surface; segment 4 narrow with slender unguis.

Gnathopod 1 with bladder-like, pilose posterior lobe on merus (see fig. 1 for the configuration in Allomelita pelucida (Sars, 1882) which resembles that of Pseudoniphargus), distally of this lobe there is a long, non-bifurcate, bent seta (merus seta). Carpus variable in length and in the number of posterior groups of setae, in females slightly longer than in males. Propodus rectangular in shape with straight palmar margin, the latter slightly convex and provided with minute denticulations (fig. 2), inner and outer side with subdistal row of notched spinules bifid at the tip with a scaled setule in the middle (fig. 3). Palmar margin well demarcated by a group of bifid spines provided with a central, scaled setule; of these spines 2 are on the outside and 3-5 on the inside, the inside group with long anterior spine and the other spines decreasing gradually in length. Gnathopod 2 not provided with pilose surfaces. Carpus triangular, in female sometimes longer than in male. Propodus stouter and more variable in shape than that of gnathopod 1. Important sexual differences sometimes occur in the shape of the propodus. Palmar margin oblique and variably curved, provided with small denticulations, in- and outside with subdistal row of notched spinules of similar ultrastructure as in gnathopod 1. Palmar angle demarcated by a group of 3 (sporadically 4) strong and setule-tipped spines, two of which inserted along the palmar margin itself, the other(s) more inside.

Coxal plates 1-4, medium to deep (fig. 4). Plate 4 with posterior excavation of varying depths. Coxal plates 5 and 6 anterolobate; plate 7 non-lobate. Coxal gills with basal stalk, on gnathopod 2 and pereiopods 3 to 6 ; stalk in females often somewhat longer than in males. Oostegites linear, with 3-12 setae on gnathopod 2 and pereiopods 3 to 6. Pereiopods 3 and 4 similar (but for coxal plates). Pereiopods 5 to 7 of increasing length, not setose. Shape 


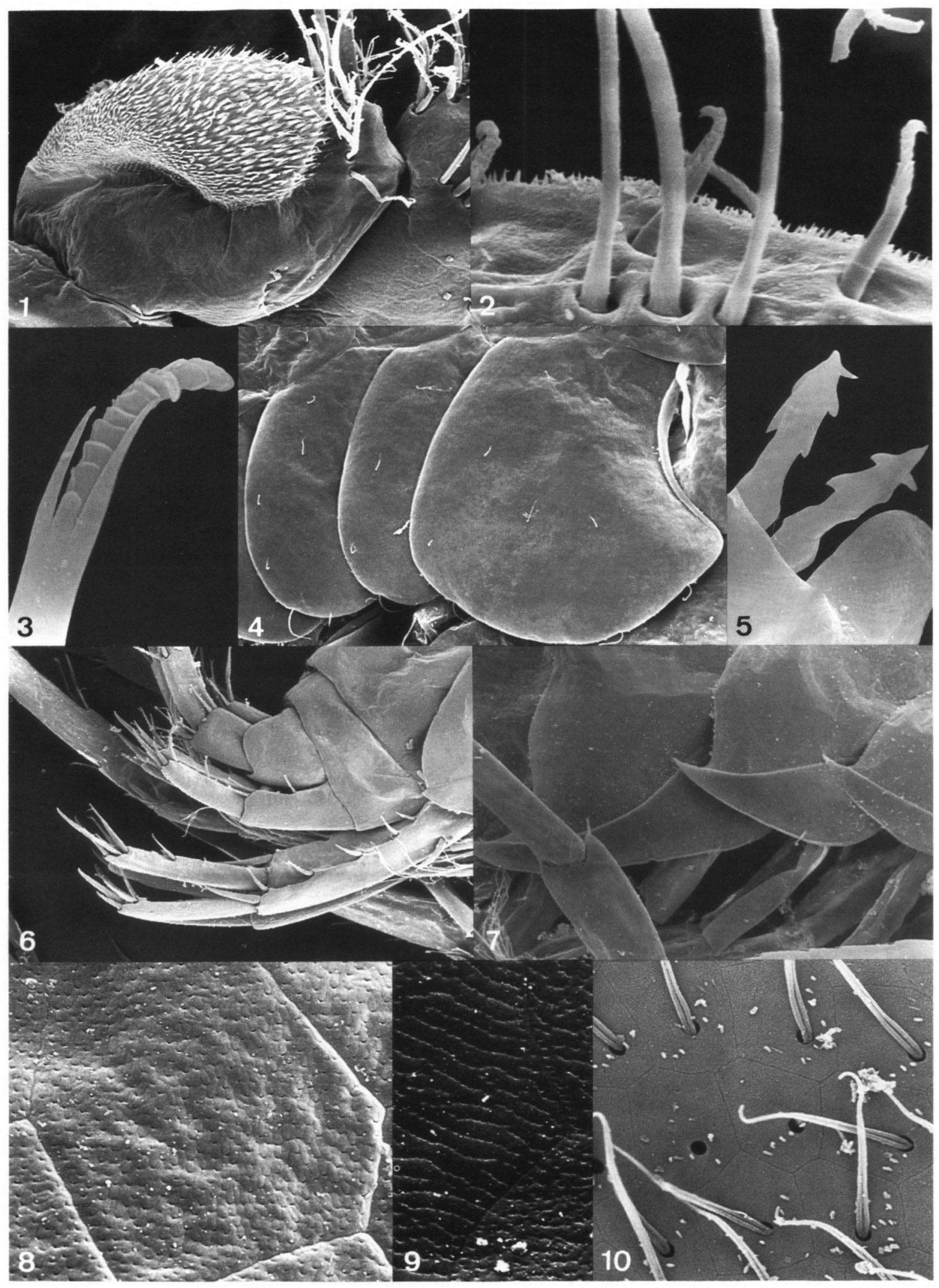


of basis varies from oval to rectangular, in females usually with more convex margins and more overhanging posterodistal angle. Claws of P5-P7 show varying degrees of elongation.

Pleopods basically similar, but decreasing in length posteriorly. Prepeduncle short, twice as wide as long. Peduncle slender and elongate, without marginal setation, distomedially with 2 pine-tree shaped retinacula (fig. 5). Bother rami of equal length, first segment of inner ramus the longest, distomedially with split seta.

Uropod 1 (fig. 6) without ecdysial spine on prepeduncle. Peduncle slender with 1 or sometimes 2 basoventral spines, dorsal cuticular ridge provided with row of spines, 1 long distomedial spine, and 2 distolateral spines. Rami well developed but shorter than peduncle, slightly curved, exopodite often slightly shorter than endopodite. Uropod 2 much smaller than uropod 1. Uropod 3 with 1 segmented exopodite, endopodite scale-like. Peduncle and exopodite elongated in some species, this elongation being stronger in males than in females, consequently sexual differences occur. Endopodite with short lateral seta, and 1 or 2 apical spinules. Exopodite with spine groups along margins, the number of spine groups increases while sometimes the size of the spines decreases with elongation of exopodite.

Telson subquadrate with shallow distal emargination varying in depth, rarely non-emarginate, proximal part of dorsal surface with some minute spinules, sublaterally 2 sensory setules on either side, distally a group of spines on either side. Sexual differentiation in telson length sometimes occurs.

Epidermal surface (figs. 8 \& 9) with irregular, 5- to 7sided polygones, strongly defined by deeply grooved perimeters. Small pores occupy entire area of polygone, randomly or in distinct rows; large, rare, circular pores occur only on the perimeters of the polygones and do not clearly belong to a particular epidermal cell.

'Type-species: Pseudoniphargus africanus Chevreux, 1901 by original designation and monotypy.

\subsection{Distribution and biology}

The genus Pseudoniphargus has an AtlanticMediterranean distribution. Records are known from the following regions (most of the records published before 1980 are summarized in Stock (1980a) and not explicitly referred to here): Bermuda (Stock et al., 1986); Faial and Santa Maria, Azores; Funchal, Madeira; western Canary Islands (Stock, 1988; Sanchez, in prep.); Middle Atlas, Morocco (Boutin \& Coineau, 1988); northern Algeria (Stock, 1980a; Notenboom \& De Winter, 1986; unpublished); Oued-ed-Demane, Tunisia; western Portugal and Galicia, northwestern Spain (Notenboom, 1987b); Cantabrian Mountains and southwestern slopes of the Pyrenees, northern Spain (Notenboom, 1986); Pyrénées-Atlantiques, southwestern France (unpublished); Catalan Hills, Tarragona, Spain (Margalef, 1970); Betic Cordillera, southern Spain (Notenboom, 1987a); Mallorca, Menorca, and Ibiza, Balearic Islands (Gourbault \& Lescher-Moutoué, 1979; Stock, 1980a and pers. comm.; Pretus, in prep.); Mediterranean coast of France; Bonifacio, Corsica; Monte Cristo Island, Tuscany Archipelago, Italy; Mola di Bari, Apulia, southeastern Italy; Linosa and Lampedusa Islands, Italy (Ruffo, 1982); Sicily, Italy (Caruso \& Costa, 1978); Adriatic coast of Yugoslavia (Karaman, 1982; Sket, 1986).

The species of the genus have limited distributional areas with the exception of the marine/mixohaline Mediterranean $P$. adriaticus. The Iberian Peninsula, for example, is a vast landmass with suitable subterranean habitats almost everywhere, but nevertheless the distribution of Pseudoniphargus shows a disjunct pattern (Notenboom, 1988c). Occasionally, sympatry of species has been recorded (Stock et al., 1986; Notenboom, 1987a), in hyporheic habitats of a single river in southern Spain ( $P$. illustris and $P$. latipes), and in wells at the oligohaline and $\beta$-mesohaline zone of Bermuda ( $P$. carpalis and $P$. grandimanus). In both cases

Figs. 1-10. Scanning electron photomicrographs of external morphological features: 1, Allomelita pelucida, pilosity of merus of 1st gnathopod; 2, Pseudoniphargus longicarpus, palmar margin of 1 st gnathopod; 3, P. margalefi, tip of notched spinule on palmar margin of 1 st gnathopod; $4, P$. montanus, coxal plates $2-4 ; 5, P$. margalefi, retinacula of 1 st pleopod; 6, P. montanus, urosome; 7, $P$. illustris, epimeral plates; $8, P$. illustris, epidermal cell of head with randomly distributed micropores; $9, P$. longicarpus, epidermal cells of 1 st pereion segment with micropore arrangements; 10, Hadzia fragilis, epidermal cells of 1 st pereion segment with pores and associated microtrichs. 
the sympatric species are clearly morphologically distinct, and the smaller geographical range of one of them fits into the wider range of the other one (the range of $P$. carpalis fits into that of $P$. grandimanus, and the range of $P$. illustris into that of $P$. latipes).

Very little is known about the biology of the various species of the genus. No experimental work has been done on their growth and development, life cycle, reproductive strategy, food choice, habitat preference, population structure, etc. Aspects of the biology of Pseudoniphargus pointed out in the present paper are based only on field observations (Notenboom, 1986, 1987a; Sket, 1986; Stock et al., 1986), on the study of the external morphology, and on our cognizance of the biology of other stygobiont amphipods. Some species of Niphargus have been the subject of much experimental work on their biology and ecological properties (see Ginet, 1960, and pertaining references given by Gibert, 1986).

Species of Pseudoniphargus have been found in a large range of habitats. A single species, $P$. adriaticus, found along the northern belt of the Mediterranean, is recorded from interstitial habitats of coarse sand and gravel beaches washed by seawater. It is also found in mixohaline waters of caves and springs, and in estuarine interstitial habitats along the seacoast, and has even been recorded from a sulphureous coastal spring. In a study of the ecology of the mixohaline hypogean fauna along the Yugoslav coast, Sket (1986) concluded that $P$. adriaticus is an extremely euryoecious species. The Bermudian $P$. grandimanus has a preference for oligohaline groundwater (in wells), but has also been found in mesohaline and euhaline water lenses, such as present in anchialine caves (Stock et al., 1986). Many other species have been discovered in purely freshwater underground habitats. In the inland waters of the Iberian Peninsula, the phreatic and hyporheic waters apparently constitute the most important habitats of Pseudoniphargus species. In caves, specimens of Pseudoniphargus prefer a close contact with the muddy or gravelly substrate and are only sporadically found free- swimming in the water body. A few records of Pseudoniphargus are availabe from oligoxic environments: it was found in two inland localities, viz., a well and hyporheic water, with 0.5-0.7 mg/l dissolved oxygen (Notenboom, 1987a).

Upon the whole, the morphology of members of the genus is very similar. No correlation has been found between a certain external morphological structure of a species and its occurrence in a preferred habitat, e.g., microporous vs. crevicular. The absence of ecophenotypes is best exemplified by the striking feature of the strongly elongate male 3rd uropod exhibited by species living in cave waters, but as well in species found in wells and in interstices of sediments in marine to limnetic waters. Members of the genus do not possess such morphological structures as natatory setae or widened rami of uropod 3 , suggesting a freeswimming mode of life in larger water bodies. The great variety of habitats, salinities, and altitudes occupied by species of Pseudoniphargus suggests a rather large ecological amplitude for the genus. However, the manifest ecological divergence is not reflected in any particular morphological differentiation.

Clear secondary sexual differences occur in a number of species, exhibited in particular in the gnathopods and third uropod. The peduncle of the coxal gills of females is often slightly longer than it is in males, a phenomenon that may be related to marsupial brood care. A gill with a longer stalk is less confined by the marsupium, and therefore better aerated. No other observations are available about the reproductive strategy. Precopula or copulation has not been recorded. Absence of a precopula stage and a short period of copulation is usual in Niphargus and in other stygobionts such as the isopod Stenasellus, and may be an adaptation to interstitial life (Magniez, 1978). The number of eggs carried by females in the marsupium is small (3 to 11). In analogy to other stygobiont, especially interstitial crustaceans living in energy-poor habitats, members of Pseudoniphargus may have but limited dispersal capabilities, a low metabolic rate, delayed 
reproduction with a low progeny, and an increased longevity (Coineau, 1984; Holsinger \& Culver, 1988).

\section{THE PHYLOGENETIC POSITION OF PSEUDONIPHARGUS}

\subsection{Classificatory problems}

The outgroup analysis executed in the present paper is a deepening of the hypothesized relationships of Pseudoniphargus as tentatively presented in Notenboom (1988a). Consolidation of the outgroup hypothesis is achieved by implication of a larger group of supposed interrelated taxa and a numerical phylogenetic analysis of that cluster. Phylogenetic placement of Pseudoniphargus, thus placed within a group of taxa with which it shares apomorphous characters, encounters great difficulties. This appears to be a rather universal problem within gammaridean amphipods. For example, it is striking that evidence for the monophyly of biogeographically important stygobiont groups such as crangonyctoids, bogidielloids, and hadzioids is lacking. The actual classification of superfamilies and families (according to Bousfield, 1982, 1983) is liable to considerable alterations when possibly new "intermediate" taxa are discovered or when other characters are considered to be of greater taxonomic significance.

Schram (1986: 177) has opted for the Bousfield (1983) classification because "the methodology used ....... is repeatable and thus the methodology's results are testable", adding that "Bousfield and associates use basically phenetic techniques that utilize numerical averages to group taxa. Such an approach would give at best a 'first estimate' of relationships". Although the Bousfield system in general meets support, there is no consensus whatsoever between different amphipodologists as regards many details of the system, for example whether a cluster of taxa is monophyletic or not, or concerning the rank of a given group of genera. The Bousfield classification has its merits, but needs a phylogenetic deepening through revisions (not by "armchair" analysis) of problematic groupings, the exploration of new, not traditionally used characters, and the application of modern phylogenetic theories. It must be emphasized that most stygobiont amphipods explicitly belong to phylogenetically problematic groups.

Different classifications have been proposed for the genus Pseudoniphargus (see Notenboom, 1988a: table 2). The purpose of the present paper is to arrive at a single hypothesis of outgroup relationships of Pseudoniphargus. To this end, a merely pragmatic procedure has been followed in which suggested relationships (phenetic similarities) are evaluated and unlikely proposals eliminated. The first step in a phylogenetic approach was made in an earlier paper (Notenboom, 1988a) in which it was concluded that Pseudoniphargus and its sister group Parapseudoniphargus are best placed within Bousfield's superfamily Hadzioidea (synonymous with Melitoidea Bousfield, 1973; see Bousfield, 1977 and Barnard \& Karaman, 1980). Within the Hadzioidea, Pseudoniphargus appears to be more closely related to the melitid genera than to the hadziid ones (both clusters and the Carangoliopsidae are considered as separate families of the Hadzioidea by Bousfield, 1977). The concept of the Hadzioidea (see Bousfield, 1982) is tentatively accepted here, although its superfamilial status is strongly doubted. It is very similar to that of the melitid grouping (Melitidae sensu Bousfield, 1973, emend.) of Stock (1986a).

\subsection{Delimitation of presumedly related taxa}

Current investigations and a literature study of Pseudoniphargus and allied genera of Hadzioidea have led to the supposition that on the basis of the following criteria an interrelated group of taxa could be selected: (1) it should fit within the diagnosis of the Hadzioidea as given by Bousfield (1982); (2) presumably it should have relationships with Melita and allied genera; (3) the gnathopod 1 must be of the melitid form (sensu Barnard, 1976); (4) a posterior swelling with pilosity present on merus of gnathopod 1 
but lacking in gnathopod 2; (5) merus of gnathopod 1 with a single long bended marginal seta distally of pilose swelling; (6) segments of gnathopod 2 without pilosity; (7) mandibular molar and incisor separated by a row of setae; (8) peduncle of antennae 1 and 2 of about the same length; (9) antennae not sexually dimorphic; (10) absence of ecdysial spine on prepeduncle of uropod $1 ;$ (11) non-foliacious or natatory uropod 3.

For practical purposes the taxa thus delimitated (see table I) are supposed to have evolved from a common ancestral species. This "a priori" acceptance is the foundation of the analysis presented here. Affinities among members of this selected group have often been discussed in the literature (Barnard, 1976; Barnard \& Barnard, 1983; Ruffo, 1979; Stock, 1980b, 1984), which suggests the recognition of this group as a natural taxon by experienced amphipodologists.

Members of the taxa of table I are marine and occur in shallow-littoral, coastal, often infaunal, habitats or are hypogean in coastal brackish and fresh groundwaters. The nonmarine members of the group are all stygobiont

TABLE I

Supposedly interrelated taxa subjected to the outgroup analysis.

\begin{tabular}{|c|c|}
\hline Taxa selected & Sources \\
\hline Abludomelita G. Karaman, 1981 & Karaman (1981, 1982); Lincoln (1979). \\
\hline Allomelita Stock, 1984 & Stock (1984). \\
\hline Anchialella Barnard, 1979 & Barnard (1979). \\
\hline \multicolumn{2}{|l|}{ Eriopisa complex (sensu Karaman, 1984a) } \\
\hline Confodiopisa G. Karaman, 1984 & Stock $(1980 b, 1983)$ \\
\hline Eriopisa Stebbing, 1890 & $\begin{array}{l}\text { Karaman (1984a); Lincoln (1979); } \\
\text { McKinney et al. (1978). }\end{array}$ \\
\hline Flagitopisa G. Karaman, 1984 & Chilton (1921); Karaman (1984a). \\
\hline Impertiopisa G. Karaman, 1984 & Ruffo \& Schiecke (1975). \\
\hline \multicolumn{2}{|l|}{ Psammogammarus S. Karaman, 1955} \\
\hline P. caecus S. Karaman, 1955 & Ruffo \& Schiecke (1975). \\
\hline P. longiramus (Stock \& Nijssen, 1965) & Stock \& Nijssen (1965). \\
\hline P. initialis Stock \& Sanchez, 1987 & Stock \& Sanchez (1987). \\
\hline Roropisa G. Karaman, 1984 & Griffiths (1974); Stock \& Platvoet (1981). \\
\hline Tunisopisa Stock, 1980 & Gauthier (1936); Monod (1938). \\
\hline Vicitopisa G. Karaman, 1984 & Ledoyer (1982). \\
\hline Victoriopisa G. Karaman \& J. L. Barnard, 1979 & Karaman (1984a); Karaman \& Barnard (1979); Ledoyer (1982). \\
\hline Galapsiellus Barnard, 1976 & Barnard (1976); Monod (1970). \\
\hline Josephosella Ruffo, 1985 & Ruffo (1985). \\
\hline Maleriopa J. L. Barnard \& G. Karaman, 1982 & Ledoyer (1978). \\
\hline \multicolumn{2}{|l|}{ Melita Leach, 1814} \\
\hline M. valesi G. Karaman, 1978 & Karaman $(1978 b, 1982)$ \\
\hline M. bulla S. Karaman, 1955 & Karaman $(1978 b, 1982)$ \\
\hline M. palmata (Montagu, 1804) & Karaman (1982); Lincoln (1979). \\
\hline Nainaloa G. Karaman \& J. L. Barnard, 1979 & Bousfield (1971) \\
\hline Paraniphargus Tattersal, 1925 & $\begin{array}{l}\text { Barnard \& Barnard (1983); Schellenberg (1931); } \\
\text { Tattersal (1925). }\end{array}$ \\
\hline Parapseudoniphargus Notenboom, 1988 & Notenboom (1988a). \\
\hline Phreatomelita Ruffo, 1979 & Ruffo (1979). \\
\hline Psammoniphargus Ruffo, 1956 & Ruffo (1956). \\
\hline Pseudoniphargus Chevreux, 1901 & Stock $(1980 \mathrm{a})$; Notenboom $(1986 ; 1987 \mathrm{a}, \mathrm{b})$ \\
\hline Quadrus G. Karaman, 1984 & Karaman (1984b). \\
\hline Rotomelita Barnard, 1977 & Barnard (1977). \\
\hline Tegano J. L. Barnard \& G. Karaman, 1982 & Bousfield (1970) \\
\hline
\end{tabular}


and mostly occur in oceanic islands or on continents at rather short distances from the present sea shores.

The systematic division of the Eriopisa complex according to Karaman (1984a) is supplemented by the recently described Psammogammarus initialis Stock \& Sanchez, 1987. The species of Psammogammarus are treated separately because they differ in characters 5 , 14, and 15 (table II) which are considered of diagnostic importance in other genera. Psammogammarus initialis is the only species of the Eriopisa complex sensu Karaman (1984a) with coxal plate 3 slightly longer than wide (character 15). Most of the genera listed in table I are mono- or oligotypic, with the exception of Abludomelita, Melita and Pseudoniphargus. Of the genus Melita only 3 species have been included in the analysis, viz., the type-species of the genus, $M$. palmata, and a cluster formed by two closely related infaunal species $M$. valesi and $M$. bulla.

Such hadzioid amphipods as those of the Hadzia complex, the Weckelia group, and the Eriopisella group may be closely related to the taxa of table I, but they differ in certain features through which they do not fit all given criteria (vide supra). Species of the Hadzia complex (Hadzia S. Karaman, 1932, Metaniphargus Stephensen, 1933, Metahadzia Stock, 1977, Liagoceradocus Barnard, 1965, and (perhaps) Saliweckelia Stock, 1977) and the Weckelia group (see Holsinger, 1986) differ in having pilosity on the segments of gnathopod 2, an ecdysial spine on the prepeduncle of uropod 1, and often a natatory 3rd uropod.

An additional argument for the idea that most probably the members of the Hadzia complex are not closely related to the taxa of table I comes from observations on surface microstructures by scanning electron microscopy (SEM). Members belonging to a selection of taxa of table I (Allomelita pellucida (Sars, 1882), Roropisa atlantica (Stock \& Platvoet, 1981), Psammogammarus longiramus (Stock \& Nijssen, 1965), Melita palmata (Montagu, 1804), Parapseudoniphargus baetis Notenboom, 1988, and several species of Pseudoniphargus) show micropores with very small microtrichs protruding from them (figs. 8 \& 9). In contrast, Hadzia fragilis $\mathrm{S}$. Karaman, 1932 and Metaniphargus curasavicus curasavicus Stephensen, 1933, which belong to the Hadzia complex, have rather large, simple and lanceolate microtrichs associated with the pores (fig. 10). Moreover, males of some of the species belonging to the Hadzia complex possess swellings and protuberances on articles of pleopod 3 (Metaniphargus partim, Saliweckelia) or uropod 2 (Metahadzia partim), which are not found in other hadzioids (Stock, 1977, 1985; Notenboom, 1988b). The potential to develop these sex-linked structures may be a synapomorphy or underlying synapomorphy (Saether, 1983) in the Hadzia complex or at least in one of its subgroups.

The Eriopisella complex (see Karaman, $1984 b$ ) is not included because it deviates from the members of the selected taxa (table I), among other things by (1) the absence of a row of setae between the molar and the incisor of the mandible, and (2) in that the 2nd gnathopod is of the same size as the first (see Stock, 1980b).

\subsection{Numerical phylogenetic analysis}

The characters selected for numerical analysis are listed in table II and their distribution over the amphipod body is diagrammatically presented in fig. 11. The distribution of character states over the taxa is shown in table III. The characters of Abludomelita, with the exception of character 3 , are considered the ancestral states because many of its character states occur in marine taxa outside the group under study. An exception is made for character 3 , the terminal setation of the mandible palp, since a fully developed setation widely occurs within other gammaridean amphipods, as opposed to the reduced setation as found in Abludomelita.

Results of compatibility analysis are shown in table IV. Several largest cliques comprising 11 character states are found. All these cliques agree in 7 strongly compatible character states (underlined in table IV), while 8 supplemental states are not in the intersection of the largest cliques (not underlined in table IV). Fourteen 
TABLE II

Character transformation series selected for outgroup analysis: $0=$ plesiomorphous state; $1-4=$ apomorphous states in transition series; $1^{\prime}=$ alternative apomorphous state.

1. Antenna 1: accessory flagellum.

0: 3- or more segmented;

1: 1- or 2-segmented.

2. Ommatids.

0 : present;

1: absent.

3. Mandible: development of mandibular segments.

0: 3-segmented with fully developed setation (presence of A, B, D, E setae sensu Stock, 1974);

1: 3-segmented with terminal E-setae and ventral D-setae only;

2: 3-segmented with terminal E-setae only;

3: 2-segmented;

4: 1-segmented or absent.

4. Lower lip: inner lobes.

0 : present;

1: absent.

5. Maxilla 1: number of setae of distal row on inner lobe.

0: $>10$;

1: $5-10$;

2: $1-4$.

6. Maxilla 1: number of spine teeth on outer lobe.

$0: 9$;

1: 6-8.

7. Maxilla 2: setation on inner lobe.

0 : with medial and oblique facial row;

1: oblique facial row lacking, medial row present;

2: medial and facial rows lacking.

8. Maxilla 2: setation on outer lobe.

0 : distal row of setae uniform of one type only;

1: distal setae separated into two rows of different types.

9. Maxilliped: spines along medial margin of outer lobe.

0 : present;

1: absent.

10. Coxal plate 1.

0 : longer than wide;

1: quadrate or wider than long.
11. Coxal plate 1 .

0 : dorsally tapering;

1: margins subparallel;

$1^{\prime}$ : anteroventrally projecting.

12. Gnathopod 1: palmar angle.

0 : not demarcated by a group of bifid spines;

1: well demarcated by a group of bifid spines.

13. Gnathopod 1: palmar margin.

0 : posterior part of margin bulged;

1: margin slightly convex.

14. Gnathopod 2: sexual dimorphism of propodus.

0 : strongly expressed in shape of propodus and the morphology of palmar margin;

1: weakly expressed in shape of propodus only;

2: absent.

15. Coxal plate 3: shape.

0 : longer than wide or quadrate;

1: distinctly wider than long.

16. Urosome: dorsal spines.

0 : on one or more segments;

1: lacking.

17. Uropod 3.

0 : parviramous;

1: variiramous.

18. Uropod 3: exopodite.

0: 2-segmented;

1: 1-segmented.

19. Uropod 3: segment 2 of exopodite.

0 : short or absent;

1: elongated and flattened.

20. Telson.

0: almost entirely or completely cleft;

1: basal half fused;

2: almost entirely fused.

21. Telson: shape of the lobes.

0 : apically tapering;

1: apically truncate. character states are strongly incompatible and excluded from any clique. The compatibility analysis does not result in a single cladogram, since several cliques are found which only partly vary in composition. The large amount of incompatibility between many characters means that parallelisms, convergences, or reversals have to be assumed to explain the distribution of character states among the taxa. The number of potential apomorphies (29) is slightly higher than the theoretical minimum number (number of taxa minus two) required for a dichotomous resolution of the cladogram in case the characters are not homoplasous. 


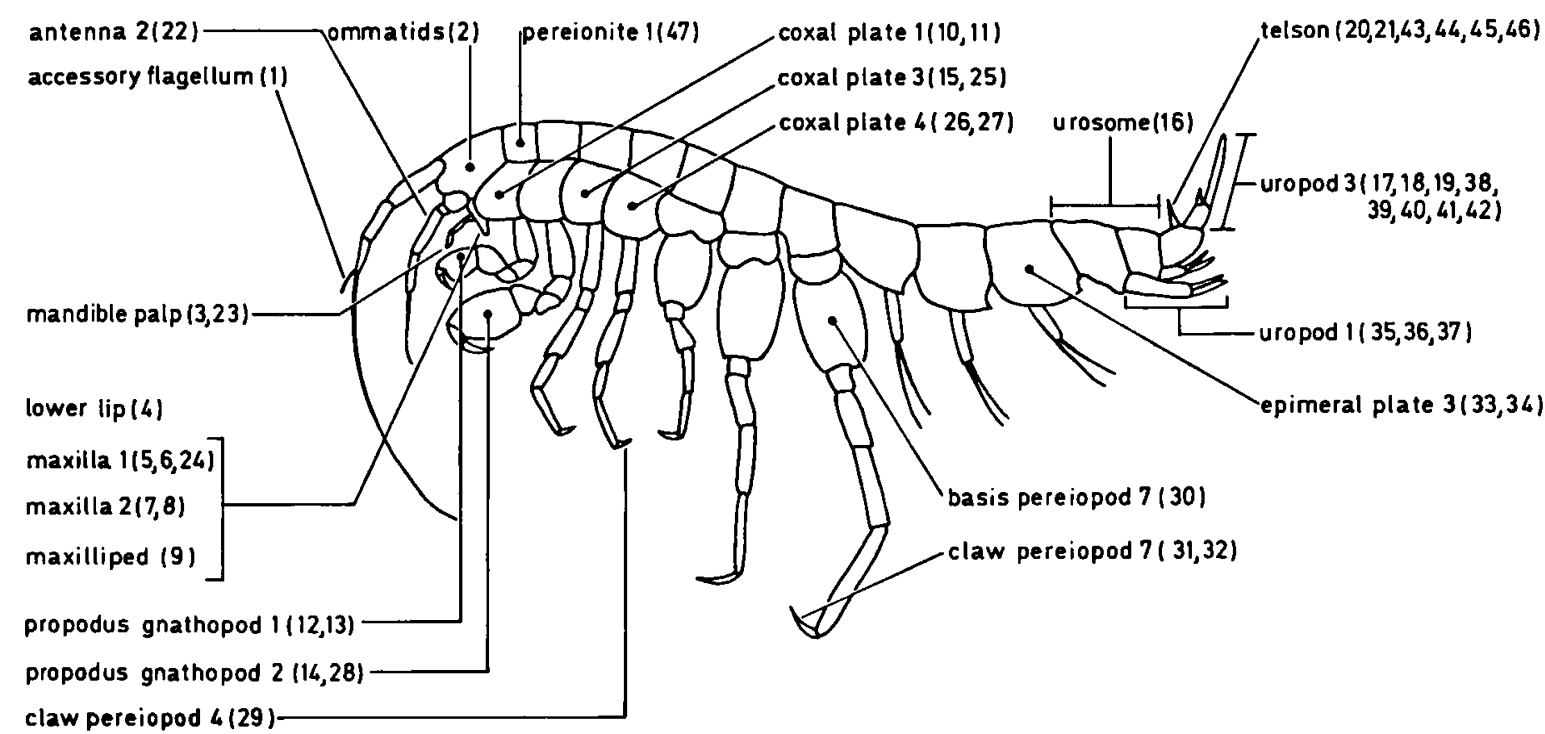

Fig. 11. Sketch of a hadzioid amphipod, the characters used in this study indicated.

Table III

Taxa interrelated with Pseudoniphargus and the distribution of character states. Unknown states are indicated with "??" (See table II for description of characters and explanation of character state numbers.)

\begin{tabular}{|c|c|c|c|c|c|c|c|c|c|c|c|c|c|c|c|c|c|c|c|c|c|}
\hline & 1 & 2 & 3 & 4 & 5 & 6 & 7 & 8 & 9 & 10 & 11 & 12 & 13 & 14 & 15 & 16 & 17 & 18 & 19 & 20 & 21 \\
\hline Abludomelita & 0 & 0 & 1 & 0 & 0 & 0 & 0 & 0 & 0 & 0 & 0 & 0 & 0 & 0 & 0 & 0 & 0 & 0 & 0 & 0 & 0 \\
\hline Allomelita & 1 & 0 & 0 & 0 & 2 & 0 & 2 & 1 & 0 & 0 & 0 & 1 & 1 & 0 & 0 & 0 & 0 & 1 & 0 & 1 & 0 \\
\hline Anchialella & 1 & 1 & 1 & 0 & 2 & 1 & 1 & 0 & 0 & 0 & 1 & 0 & 1 & $1 / 2$ & 0 & 1 & 0 & 0 & 0 & 0 & 0 \\
\hline \multicolumn{22}{|l|}{ Eriopisa complex: } \\
\hline Confodiopisa & 1 & 1 & 1 & 0 & 1 & 0 & 0 & 0 & 1 & 1 & 1 & 1 & 1 & 0 & 1 & 1 & 1 & 0 & 1 & 0 & 0 \\
\hline Eriopisa & 1 & 1 & 1 & 0 & 0 & 0 & 0 & 0 & 1 & 1 & $1^{\prime}$ & 0 & 1 & 1 & 1 & 1 & 0 & 0 & 1 & 0 & 0 \\
\hline Flagitopisa & 1 & 1 & 1 & 0 & 0 & 1 & 0 & 0 & 0 & 1 & $1^{\prime}$ & 0 & 1 & 1 & 1 & 1 & 0 & 0 & 1 & 0 & 0 \\
\hline Impertiopisa & 1 & 1 & 1 & 0 & 1 & 1 & 0 & 0 & 1 & 1 & 1 & 1 & 1 & 0 & 1 & 1 & 0 & 0 & 1 & 0 & 0 \\
\hline Psammogammarus caecus & 1 & 1 & 1 & 0 & 1 & 0 & $\mathbf{0}$ & 0 & 0 & 1 & 1 & 1 & 1 & 0 & 1 & 1 & 1 & 0 & 1 & 0 & 0 \\
\hline$P$. longiramus & 1 & 1 & 1 & 0 & 0 & 0 & 0 & 0 & 0 & 1 & 1 & 1 & 1 & 2 & 1 & 1 & 1 & 0 & 1 & 0 & 0 \\
\hline$P$. initialis & 1 & 1 & 1 & 0 & 0 & 0 & 0 & 0 & 0 & 1 & 1 & 1 & 1 & 0 & 0 & 1 & 1 & 0 & 1 & 0 & 0 \\
\hline Roropisa & 1 & 1 & 1 & 0 & 0 & 0 & 0 & 0 & 0 & 1 & $1^{\prime}$ & 0 & 1 & 1 & 1 & 1 & 0 & 0 & 1 & 0 & 0 \\
\hline Tunisopisa & 1 & 1 & 1 & 0 & 0 & 0 & 0 & 0 & 0 & 1 & 1 & 1 & 0 & 1 & 1 & 1 & 0 & 0 & 0 & 0 & 0 \\
\hline Vicitopisa & 1 & 1 & 2 & 0 & 0 & 0 & 0 & 0 & 0 & 1 & 1 & 0 & 1 & 1 & 1 & 1 & 0 & 0 & 0 & 0 & 0 \\
\hline Victoriopisa & 1 & 1 & 1 & 0 & 0 & 0 & 0 & 0 & 0 & 1 & 1 & 1 & 1 & 1 & 1 & 1 & 0 & 1 & 1 & 0 & 0 \\
\hline Galapsiellus & 1 & 1 & 2 & 0 & 2 & 1 & 1 & 0 & 0 & 0 & 1 & 0 & 1 & $1 / 2$ & 0 & 1 & 0 & 0 & 0 & 0 & 0 \\
\hline Josephosella & 1 & 0 & 2 & 0 & 2 & 1 & 2 & 0 & 0 & 0 & 1 & $?$ & 1 & 1 & 0 & 1 & 0 & 0 & 0 & 0 & 0 \\
\hline Maleriopa & 1 & 0 & 2 & 0 & 2 & 1 & 2 & 0 & 0 & 1 & $1^{\prime}$ & 0 & 1 & 2 & 0 & 1 & 0 & 0 & 0 & 0 & 0 \\
\hline Melita valesi/bulla & 1 & 0 & 1 & 0 & 1 & 0 & 1 & 0 & 0 & 0 & 1 & 0 & 0 & 1 & 0 & 0 & 0 & 1 & 0 & 0 & 0 \\
\hline M. palmata & 0 & 0 & 1 & 0 & 1 & 0 & 1 & 0 & 0 & 0 & 0 & 0 & 0 & 0 & 0 & 0 & 0 & 1 & 0 & 0 & 0 \\
\hline Nainaloa & 1 & 0 & 2 & 0 & 2 & 0 & 2 & 0 & 0 & 0 & 1 & 0 & 1 & 1 & 0 & 0 & 0 & 0 & 0 & 0 & 1 \\
\hline Paraniphargus & 1 & 1 & 2 & 0 & 2 & 1 & 2 & 0 & 0 & 0 & 1 & 0 & 1 & 2 & 0 & 1 & 0 & 1 & 0 & 0 & 0 \\
\hline Parapseudoniphargus & 1 & 1 & 0 & 0 & 2 & 1 & 2 & 1 & 0 & 0 & 0 & 1 & 1 & 2 & 0 & 1 & 0 & 1 & 0 & 2 & 0 \\
\hline Phreatomelita & 1 & 1 & 4 & 1 & 2 & 0 & 1 & 0 & 0 & 0 & 1 & 0 & 1 & $1 / 2$ & 0 & 1 & 0 & 1 & 0 & 0 & 0 \\
\hline Psammoniphargus & 1 & 1 & 4 & 1 & 1 & 1 & 1 & 0 & 0 & 0 & 1 & 0 & 1 & 1 & 0 & 0 & 0 & 0 & 0 & 0 & 0 \\
\hline Pseudoniphargus & 1 & 1 & 0 & 0 & 2 & 1 & 2 & 1 & 0 & 0 & 1 & 1 & 1 & 1 & 0 & 1 & 0 & 1 & 0 & 2 & 0 \\
\hline Quadrus & 1 & 0 & 4 & 0 & 2 & 0 & 1 & 0 & 0 & 0 & 1 & 0 & 0 & 1 & 0 & 0 & 0 & 0 & 0 & 0 & 0 \\
\hline Rotomelita & 0 & 1 & 2 & 0 & 2 & 0 & 2 & 0 & 0 & 0 & 1 & 0 & 0 & 2 & 0 & 0 & 0 & 0 & 0 & 0 & 1 \\
\hline Tegano & 1 & 0 & 3 & 0 & 1 & 0 & 1 & 0 & 0 & 0 & 1 & 0 & 0 & 0 & 0 & 1 & 0 & 0 & 0 & 0 & 0 \\
\hline
\end{tabular}




\section{TABLE IV}

Monophyletic groups and their synapomorphies found by means of a compatibility method in outgroup analysis. Underlined are characters present in the intersection of all largest cliques. Note that internal discrepancy exists with regard to the monophyletic groups based on characters (non-underlined) not present in the intersection of all largest cliques.

Monophyletic group

Synapomorphous characters (cf. table II)

1. Eriopisa complex, Maleriopa 10

a. Eriopisa complex, except for Tunisopisa, Vicitopisa

b. Confodiopisa, Impertiopisa, Eriopisa

c. Confodiopisa, Psammogammarus

2. Nainaloa, Rotomelita

3. Phreatomelita, Psammoniphargus

4. $3+$ Quadrus

5. $4+$ Tegano

6. Pseudoniphargus, Parapseudoniphargus

7. $6+$ Allomelita

8. 5+2, Vicitopisa, Galapsiellus, Josephosella, Maleriopa, Paraniphargus

9. 7+2, Josephosella, Maleriopa, Paraniphargus

10. All taxa but 7

11. All taxa but Abludomelita and the Eriopisa complex

10
19
9
17
21
$\underline{4}$
3.4
3.3
20.2
$8,20.1$
3.2
7.2
3.1
7.1

Since homoplasies are numerous, the number of available characters is insufficient for a complete solution of phylogenetic relationships. However, homoplasies may provide weak synapomorphies locally in the cladogram.

The most parsimonious cladograms found by means of the Camin-Sokal method, thus without permitting reversals, have a consistency index of 0.3187 . The strict consensus cladogram based on more than 100 equally parsimonious solutions is given in fig. 12a. The cladograms generated under the Wagner criterion, which permits reversals, need fewer evolutionary steps than those found with the Camin-Sokal method. The strict consensus cladogram based on an evaluation of more than 100 Wagner cladograms with a consistency index of 0.3867 is given in fig. 12b. The Camin-Sokal consensus cladogram (fig. 12a) is slightly better resolved than that found through the Wagner parsimony method (fig. 12b).

Concerning the phylogenetic position of Pseudoniphargus with regard to Parapseudoniphargus and Allomelita (local outgroups), the results of compatibility and parsimony analyses are in harmony and similar to the previously postulated hypothesis (Notenboom, 1988a). However, the results provide no decisive indication for an overall outgroup hypothesis. The sister group of Pseudoniphargus is Parapseudoniphargus (henceforth these two genera are named the "Pseudoniphargus group"), a relationship which is founded on a single synapomorphy, viz., the almost entirely fused telson lobes (character 20.2). Additionally, in the Camin-Sokal parsimony analysis a number of weak synapomorphies emerged for the Pseudoniphargus group, viz., the absence of ommatids (character 2), the outer maxilla 1 lobe with 6-8 spine teeth (character 6), urosome without dorsal spines (character 16), and the weakly expressed sexual dimorphism in the 2nd gnathopod (character 14.1).

The second outgroup of Pseudoniphargus is the genus Allomelita, a relationship based on two synapomorphies, viz., the presence of two distinct distal rows of setae of different ultrastructure on the outer lobe of maxilla 2 (character 8), and the partially fused telson lobes (character 20.1). Again, parsimony methods give a number of additional weak synapomorphies. The Camin-Sokal method yields three weak synapomorphies, viz., the absence of medial and facial rows of setae on the inner lobe of maxilla 2 (character 7.2), the palmar angle of gnathopod 1 well demarcated by a group of bifid spines (character 12), and the one-segmented exopodite of the 3rd uropod (character 18). In contrast, the reversed fully developed setation of the terminal mandible palp segment (characters $3.1 \& 3.2$ ), and character 12 (see above) emerged as weak synapomorphies by application of the Wagner parsimony method. Note that the supposition of the reversed condition of character 3 as a synapomorphy in the Allomelita-Pseudoniphargus group (Wagner parsimony method) has the 
BIJDRAGEN TOT DE DIERKUNDE, 58 (2) - 1988

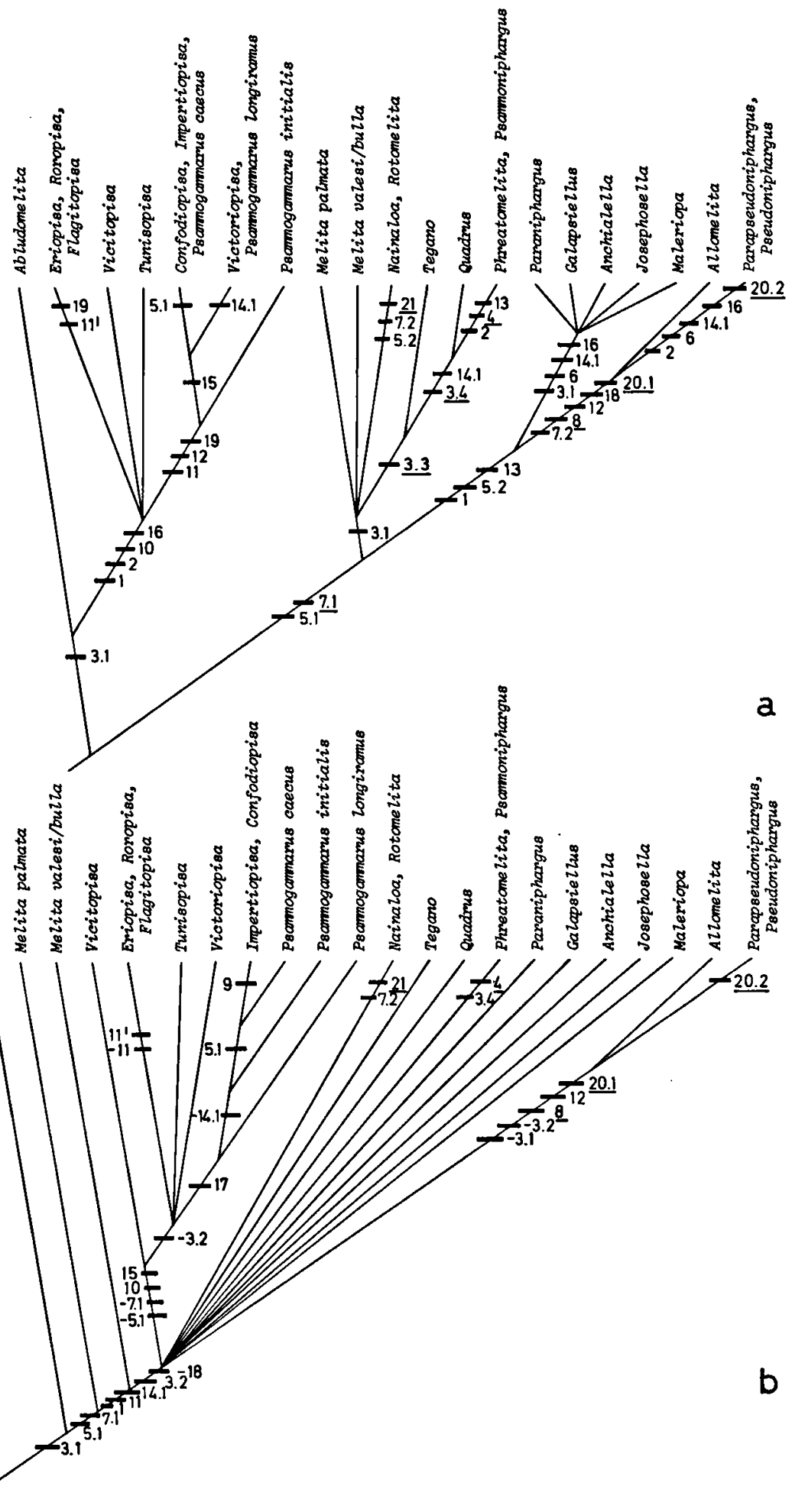

Fig. 12. Consensus cladograms of outgroup analysis of Pseudoniphargus, matching synapomorphies indicated and uniquely derived characters underlined (cf. table II): a, cladogram obtained with the Camin-Sokal parsimony method; b, cladogram obtained with the Wagner parsimony method. 
consequence that the fully developed setation of the terminal mandible palp segment must have derived independently from that in other groups of amphipods (e.g., Gammaridae) which have a similar type of chaetotaxy.

The parsimony methods yield a single weak autapomorphy for Parapseudoniphargus and Pseudoniphargus each, viz., the complete loss of sexual differentiation in the propodus of gnathopod 2 (character 14.2), and the 1 st coxal plate with subparallel margins (character 11.1), respectively. Autapomorphies for Parapseudoniphargus, not included in the analyses, are the compressed and strongly curved body, the short posterior pereiopods, and the pygidized exopodite of the 3rd uropod (Notenboom, 1988a). The tendency to (a strong) elongation of peduncle and exopodite of the 3rd uropod in Pseudoniphargus might be considered an underlying synapomorphy (Saether, 1983). Moreover, Notenboom (1988a) hypothesized that the weakly developed anterior head lobe is an autapomorphy in Pseudoniphargus. Since this character is inadequately described in the outgroups, it is excluded from the analyses. The genus Allomelita is characterized by a single autapomorphy, viz., the uniarticulated accessory flaggellum.

With respect to phylogenetic positions of the other taxa involved, the analyses strongly support sister-group relationships between: Phreatomelita and Psammoniphargus, and Nainaloa and Rotomelita. Further it is interesting to note that the parsimony and compatibility methods show but little agreement as regards the division of the Eriopisa complex. At any rate, the complex appears to be well established when parsimony methods are employed (figs. 12a, b), or, with the exception of Tunisopisa and Vicitopisa, when the compatibility method is used (table IV). The generic division of the complex as proposed by Karaman (1984a), and which has been used in this study, seems to have but little phylogenetic significance. Anyhow, the results of the parsimony methods suggest that the genera Confodiopisa, Impertiopisa and perhaps Victoriopisa should be sunk into Psammogammarus.

\section{PHYLOGENETIC RELATIONSHIPS WITHIN PSEUDONIPHARGUS}

\subsection{Character analysis}

Character analysis has been performed on the basis of diagnostic features found in a taxonomic study of Iberian material of Pseudoniphargus (Notenboom, 1986, 1987a, b). All characters refer to the external morphology of the animals. Geographical information is available, but this has not been used as a phylogenetic character because of the desired independence between phylogenetic hypotheses and the distributional data. The homology principle applied is that of similarity in position and connection with other body parts (the topographic criterion: Wiley, 1981). Unique characters not found in other species of the genus or in the outgroups are considered to be autapomorphies (table V) and are excluded from the analysis. The 26 characters which differentiate species of Pseudoniphargus and which

\section{TABLE V}

Autapomorphous characters (non-homoplasous) within the genus Pseudoniphargus.

adriaticus. Males with 4 dorsoposterior teeth on urosomite 2 (Karaman, 1978a; not confirmed by personal observations).

burgensis. Maxilla 1 outer lobe with 6 spine teeth, inner lobe with a single seta.

callaicus. Distomedial spine on peduncle of uropod 1 lacking.

gracilis. Dactylus of claw of pereiopod 7 very slender with minute unguis.

granadensis. Telson with apical and subapical group of spines on either side.

grandis. Telson lobes distaly flattened with a row of strong spines.

illustris. Outer lobe of maxilla 1 with combed spines. Pereiopod 5 shorter than pereiopod $4^{*}$

latipes. Propodus of gnathopod 1 widened.

sorbasiensis. Flagellum of antenna 2 very short (much shorter than peduncle segment 5).

spiniferus. Peduncle of uropod 2 richly provided with spines.

stocki. Outer lobe of maxilla 1 with 8 spine teeth.

* A very similar condition of this character has been found also in Parapseudoniphargus, but it is considered here to have been derived independently. 
are used in the numerical analysis are listed in table VI. The diagram in fig. 11 shows the distribution of characters over the Pseudoniphargus body. The distribution of character states over the species is given in table VII. The sequential numbering of characters follows the one used in the section dealing with outgroup analysis.

The determination of the relative plesiomorphy of a series of homologues was achieved by

\section{TABLE VI}

Character transformation series used in the ingroup analysis of Pseudoniphargus. Characters marked with an asterisk are not polarized (equivocal on the outgroup node); $0=$ plesiomorphous state; $1-3=$ apomorphous states in transition series; $1^{\prime}$ = alternative apomorphous state.

22. Antenna 2: setae of terminal peduncle and proximal flagellum segments.

0 : not exceeding width of segment;

1: some setae longer than width of segment.

23. Mandible: row of setae on ventral margin of palp segment 3 (D-setae).

0 : all of similar length;

1: proximal setae distinctly longer.

24. Maxilla 1: number of setae on inner lobe.
0: 2
1:

$$
1^{\prime}: 1
$$

25. Coxal plate 3 : length/width ratio in male.

$$
0: \geq 1.77 \quad 1: 1.71-1.54 \quad 2: \leq 1.50
$$

26. Coxal plate 4: depth of posterior emargination.

$$
0: \geq 0.16 \quad 1: 0.14-0.013 \quad 2: \leq 0.010
$$

27.* Coxal plate 4: ventral margin.

0 : sparsely setose;

1: densely setose.

28. Gnathopod 2: sexual dimorphism.

0 : male propodus wider with palmar margin more oblique than in female;

1: male propodus slightly wider or similar as in female

29. Pereiopod 4: length/width ratio of claw.

$$
0: \leq 5.70 \text { 1: } \geq 6.50
$$

30. Pereiopod 7: posterior lobe of basis.

0 : well developed and distally overhanging;

1: weakly developed and distally not overhanging.

31.* Pereiopod 7: length/width ratio of dactylus.

$$
0: \leq 3.25 \text { 1: } 3.45-5.10 \quad 2: \geq 5.60
$$

32. Pereiopod 7: ratio between length of unguis and dactylus.

$0: \leq 2.05 \quad 1: 2.20-2.45 \quad$ 2: $2.60-2.90 \quad 3: \geq 3.80$

33. Epimeral plates: shape of posteroventral corner of plate 3 .

0 : rounded or subrectangular;

1: projecting.

34. Epimeral plates: spines on ventral margin of plate 3 .
0: $1-2$
1: $\geq 3$

35.* Uropod 1: marginal spines on exopodite.

0: absent;

1: present.

36. ${ }^{*}$ Uropod 1: medial spines on peduncle.

0 : absent or a single weak spine only:

1: 1 or more strong spines.

37. Uropod 1: number of spines on dorsal ridge of peduncle.

$0: \leq 2 \quad 1: \geq 3$

38. Uropod 3: sexual dimorphism.

0 : not or weakly developed;

1: clearly expressed.

39. Uropod 3: margins of exopodite in male.

0 : subparallel;

1: tapering.

40. Uropod 3: marginal spines on peduncle.

0 : absent;

1: present

41. Uropod 3: length/width ratio of peduncle in male. $0: \leq 2.90 \quad 1: 3.40-3.90 \quad 2: \geq 4.20$

42 Uropod 3: length/width ratio of exopodite in male. $0: \leq 14.0 \quad 1: \geq 16.0$

43. Telson: implantation of spines.

0 : apical 1: subapical.

44.* Telson: distal emargination.

0 : distinctly V-shaped, narrow, ca. $1 / 4$ of telson length deep;

1: hardly emarginate or wide and shallow, less deep than $1 / 4$ of telson length.

45. Telson: shape.

0 : subquadrate or slightly wider than long, similar in both sexes;

1: clearly longer than wide in male, subquadrate in female.

46.* Telson: number of spines on each side.

0 : 2 (sometimes with 3 on one side only)

1: $\geq 3$

47. Cuticula: micropores on pereionite 1 .

0 : all randomly arranged;

1: partly forming distinct rows. 
the comparison with relevant outgroups established by means of the outgroup analysis. Thus, comparisons are made with the sister group Parapseudoniphargus, and the second outgroup Allomelita. The remaining taxa of selected Hadzioidea (table I) are considered to constitute the third, unresolved, outgroup. Through variation among outgroups the polarity of a character could not be assessed in some instances. If this was the case, these characters were polarized by the program according to the most parsimonious solution.
The analysis includes qualitative, and continuous and discontinuous, quantitative characters. Qualitative characters are based on the presence or absence, or on differences in shape of certain features. Quantitative, discontinuous characters are based on counts of numbers of spines or setae on particular appendages. Counts are grouped into non-overlapping classes and intraspecific variation is restricted within a class. Quantitative, continuous characters are based on measurements of morphoclines. These measurements are used to

TABLE VII

Distribution of character states in Pseudoniphargus. (See table VI for description of characters and explanation of character state numbers.)

$\begin{array}{llllllllllllllllllllllllll}22 & 23 & 24 & 25 & 26 & 27 & 28 & 29 & 30 & 31 & 32 & 33 & 34 & 35 & 36 & 37 & 38 & 39 & 40 & 41 & 42 & 43 & 44 & 45 & 46 & 47\end{array}$

\begin{tabular}{|c|c|c|c|c|c|c|c|c|c|c|c|c|c|c|c|c|c|c|c|c|c|c|c|c|c|c|}
\hline adriaticus & 0 & 0 & 0 & 2 & 1 & 0 & 1 & 0 & 0 & 1 & 0 & 0 & 0 & 0 & 0 & $\mathbf{0}$ & 1 & 0 & 1 & 1 & 1 & 1 & 1 & 0 & 0 & 0 \\
\hline affinis & 0 & 0 & 0 & 2 & 1 & 0 & 1 & 0 & 1 & 1 & 0 & 0 & 0 & 1 & 0 & 1 & 1 & 0 & 1 & 2 & 1 & 1 & 1 & 0 & 1 & 0 \\
\hline branchiatus & 0 & 0 & 1 & 2 & 1 & 0 & 1 & 0 & 1 & 1 & 1 & 0 & 0 & 1 & 1 & 1 & 1 & 0 & 1 & 0 & 1 & 1 & 1 & 0 & & 0 \\
\hline brevipedunculatus & 0 & 0 & 0 & 1 & 1 & 0 & 1 & 0 & 0 & 1 & 0 & 0 & 1 & 0 & 0 & 1 & 1 & 1 & 0 & 0 & 0 & 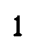 & 0 & 0 & 0 & 0 \\
\hline burgensis & 1 & 0 & $1^{\prime}$ & 0 & 1 & 0 & 0 & 1 & 0 & 2 & 0 & 0 & $1^{\prime}$ & 0 & 0 & 0 & 0 & 0 & 0 & 0 & 0 & 0 & 0 & 0 & 1 & 0 \\
\hline callaicus & 0 & 1 & 1 & 1 & 1 & 0 & 1 & 0 & 0 & 1 & 2 & 0 & 0 & 0 & 0 & 1 & 0 & 1 & 1 & 0 & 0 & 1 & 1 & 0 & 0 & 0 \\
\hline carpalis & 0 & 1 & 1 & 0 & 0 & 1 & 1 & 0 & 0 & 1 & 0 & 0 & 1 & 0 & 0 & 0 & 0 & 1 & 0 & $\mathbf{0}$ & 0 & 1 & 1 & 0 & 0 & 0 \\
\hline cazorlae & 0 & 0 & 0 & 1 & 1 & 0 & 1 & 0 & 1 & 1 & 1 & 0 & 0 & 0 & 1 & 1 & 0 & 0 & 1 & 0 & 0 & 1 & 1 & 0 & 1 & \\
\hline eborarius & 1 & 0 & 0 & 0 & 1 & 0 & 0 & 1 & 0 & 1 & 0 & 0 & $1^{\prime}$ & 0 & 0 & 1 & 0 & 0 & 0 & $\mathbf{0}$ & 0 & 0 & 0 & 0 & 1 & 0 \\
\hline elongatus & $\mathbf{0}$ & 0 & 0 & 1 & 1 & 0 & 1 & 0 & 0 & 1 & 0 & 0 & 0 & 1 & 1 & 1 & 1 & 0 & 1 & 2 & 1 & 1 & 0 & 0 & 1 & \\
\hline fragilis & 0 & 0 & 1 & 2 & 1 & 0 & 0 & 0 & 1 & 1 & 0 & 0 & 0 & 1 & 1 & 1 & 1 & 0 & 0 & 0 & 0 & 0 & 1 & 0 & 1 & 0 \\
\hline gibraltaricus & 0 & 0 & 0 & 2 & 1 & 0 & 1 & 0 & 0 & 1 & 0 & 0 & 0 & 0 & 0 & 1 & 0 & 1 & 1 & 0 & 0 & 1 & 1 & 0 & 1 & \\
\hline gorbeanus & 1 & 0 & 0 & 0 & 1 & 0 & 0 & 1 & 0 & 1 & 0 & 0 & $1^{\prime}$ & 0 & 0 & 1 & 0 & 0 & 0 & 0 & 0 & 0 & 0 & 0 & 1 & 0 \\
\hline gracilis & 0 & 0 & 0 & 2 & 1 & 0 & 1 & 0 & 0 & 2 & 3 & 0 & 0 & 0 & 1 & 1 & 0 & 0 & 0 & 0 & 0 & 0 & 1 & 0 & 1 & 0 \\
\hline granadensis & 0 & 0 & 0 & 2 & 2 & 0 & 1 & 0 & 1 & 1 & 0 & 0 & 0 & 1 & 1 & 1 & 1 & 0 & 1 & 2 & 1 & 1 & 1 & 0 & 1 & 0 \\
\hline grandiman & 0 & 1 & 1 & 0 & 1 & 1 & 0 & 0 & 0 & 1 & 0 & 0 & 1 & 0 & 0 & 0 & 0 & 1 & 0 & 0 & 0 & 1 & 1 & 0 & 0 & 0 \\
\hline grandis & 0 & 0 & 0 & 2 & 1 & 0 & 1 & 0 & 1 & 1 & 0 & 0 & 0 & 1 & 1 & 1 & 1 & 0 & 1 & 2 & 1 & 1 & 1 & 0 & 1 & 0 \\
\hline guernicae & 1 & 0 & 0 & 0 & 1 & 0 & 0 & 1 & 0 & 2 & 0 & 0 & $1^{\prime}$ & 0 & 0 & 0 & 0 & 0 & 0 & 0 & 0 & 0 & 0 & 0 & 0 & 0 \\
\hline illustris & 0 & 0 & 0 & 2 & 1 & 0 & 1 & 0 & 1 & 1 & 1 & 1 & 0 & 0 & 1 & 1 & 1 & 0 & 0 & 1 & 1 & & 1 & 1 & 0 & \\
\hline incantatus & 1 & 0 & 0 & 0 & 1 & 0 & 0 & 1 & 0 & 1 & 0 & 0 & $1^{\prime}$ & 0 & 0 & 0 & 0 & 0 & 0 & 0 & 0 & 0 & 0 & 0 & 1 & 0 \\
\hline jereanus & 1 & 0 & 0 & 1 & 1 & 0 & 0 & 1 & 0 & 1 & 0 & 0 & $1^{\prime}$ & 0 & 0 & 1 & 0 & 0 & 0 & 0 & 0 & 0 & 0 & 0 & 0 & \\
\hline latipes & 0 & 0 & 0 & 2 & 1 & 0 & 1 & 0 & 1 & 0 & 0 & 0 & 0 & 1 & 1 & 1 & 0 & 0 & 0 & 0 & 0 & 0 & 1 & 0 & 1 & \\
\hline longicarpus & 0 & 0 & 0 & 0 & 0 & 0 & 1 & 1 & 0 & 1 & 0 & 0 & 0 & 1 & 1 & 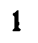 & 0 & 0 & 0 & 0 & 0 & 0 & 1 & 0 & 1 & \\
\hline margalefi & 0 & 0 & 0 & 1 & 1 & 0 & 1 & 0 & 1 & 1 & 0 & 0 & 0 & 1 & 1 & 1 & 0 & 0 & 0 & 0 & 0 & 0 & 1 & 0 & 1 & \\
\hline mateusorum & 0 & 0 & 0 & 1 & 1 & 0 & 1 & 0 & 0 & 1 & 0 & 0 & 0 & 0 & 0 & 0 & 0 & 1 & 0 & 0 & 0 & 1 & 1 & 0 & 0 & \\
\hline montanus & 0 & 0 & 0 & 0 & 0 & 0 & 1 & 0 & 0 & 1 & 0 & 0 & 0 & 1 & 1 & 1 & 0 & 0 & 0 & 0 & 0 & 0 & 1 & 0 & 1 & \\
\hline nevadensis & 0 & 0 & 0 & 2 & 2 & 0 & 1 & 0 & 1 & 1 & 2 & 1 & 0 & 1 & 1 & 1 & 1 & 0 & 1 & 0 & 1 & 1 & 1 & 0 & 1 & \\
\hline semielongatus & 0 & 0 & 0 & 0 & 1 & 0 & 1 & 0 & 0 & 1 & 0 & 0 & 0 & 1 & 1 & 1 & 0 & 0 & 1 & 0 & 0 & 1 & 1 & 0 & 1 & \\
\hline sorbasiensis & 0 & 0 & 0 & 2 & 2 & 0 & 1 & 0 & 1 & 1 & 1 & 0 & 0 & 1 & 1 & 1 & 0 & 0 & 0 & 0 & 0 & 0 & 1 & 0 & 1 & \\
\hline spiniferus & $\mathbf{0}$ & 0 & 0 & 1 & 1 & 0 & 1 & 0 & 1 & 1 & 0 & 0 & 0 & 1 & 1 & 1 & 0 & 0 & 0 & 0 & 0 & 0 & 1 & 0 & 1 & \\
\hline stocki & 0 & 0 & 0 & 2 & 1 & 0 & 1 & 0 & 1 & 1 & 0 & 0 & 0 & 0 & 0 & 1 & 1 & 0 & 1 & 2 & 1 & 1 & 1 & 0 & 1 & \\
\hline unisexualis & 0 & 0 & 0 & 1 & 1 & 0 & 1 & 0 & 1 & 1 & 0 & 0 & $1^{\prime}$ & 0 & 0 & 1 & 0 & 0 & 0 & 0 & 0 & 0 & 1 & 0 & 0 & \\
\hline vasconiensis & 1 & 0 & 0 & 0 & 1 & 0 & 0 & 1 & 0 & 1 & 0 & 0 & $1^{\prime}$ & 0 & 0 & 1 & 0 & 0 & 0 & 0 & 0 & 0 & 0 & 0 & 0 & \\
\hline vomeratus & 0 & 0 & 0 & 2 & 1 & 0 & 1 & 0 & 1 & 1 & 0 & 1 & 0 & 1 & 1 & 1 & 1 & 0 & 1 & 1 & 1 & 0 & 1 & 1 & 1 & \\
\hline
\end{tabular}


calculate ratios, which may be independent of the specimen size. Classes of counts and populations of ratios separated by gaps are considered to represent mutually exclusive states of the quantitative character.

\subsection{Explanatory notes to the characters}

The majority of characters in this study are from appendages of the pereion and the urosome. Cephalic appendages and epimeiron yield only few characters. Certain characters deserve some explanation in addition to tables VI and VII.

\section{Mouthparts}

The terminology used to describe the chaetotaxy of the terminal mandible palp segment is according to Stock (1974). D-setae are situated along the ventral margin of the terminal segment. These D-setae, although slightly increasing in length distally, are usually easily distinguishable from the group of, mostly 3 , longer setae at the tip of the palp (E-setae). The number of $\mathrm{D}$-setae may differ interspecifically and also varies with the developmental stage of the specimen. A group of longer, proximal D-setae (character 23) is found in $P$. callaicus, $P$. carpalis, and $P$. grandimanus (fig. 13). Such a differentiation of proximal D-setae is neither found in other Pseudoniphargus species, nor in closely related outgroups, and is considered apomorphous. Stock et al. (1986) have named this group "Csetae". This is incorrect, since C-setae had been defined (Stock, 1974) to be implanted on the inner surface at a short distance from the ventral margin, whereas in Pseudoniphargus the longer proximal D-setae are implanted on the margin itself in line with the remaining, shorter D-setae.

The general appearance of the inner lobe of maxilla 1 in both Pseudoniphargus and its close relatives is with 2 long distal setae, a number without intraspecific variation. In $P$. callaicus, $P$. grandimanus, $P$. carpalis, $P$. branchiatus, and $P$. fragilis the inner lobe bears 2 or 3 distal setae (character 24). The latter condition might be

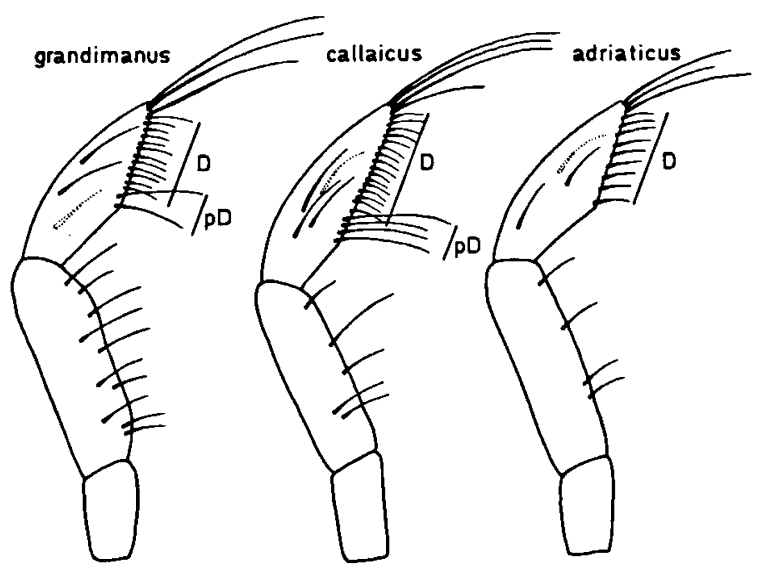

Fig. 13. Mandible palp conditions in Pseudoniphargus. D: ventral row of $\mathrm{D}$-setae; $\mathrm{pD}$ : proximal differentiated group of D-setae.

either polymorphic or results from developmental differences between specimens. In any case, the appearance of 3 distal setae on the inner lobe of maxilla 1 in individuals of a species is considered to be apomorphous. The presence of a single seta on the inner lobe of maxilla 1 in $P$. burgensis is considered an autapomorphy in that species.

\section{Gnathopods}

Sexual differentiation of the proportions of the gnathopods, especially the second, are, barring some dubious cases, found in all species of the genus. However, the phenomenon is expressed to different degrees (character 28). Basically, the carpus and propodus are slightly more slender in the female than in the male. Conversely, the male propodus is distinctly wider than that of the female in $P$. incantatus, $P$. guernicae, $P$. vasconiensis, $P$. gorbeanus, $P$. burgensis, $P$. fragilis, and $P$. grandimanus, and is usually concomitant with a more oblique palmar margin (fig. 14). Strong differences between the sexes in the shape and configuration of the armature of the palmar margin itself are not found within Pseudoniphargus (character 14), although they are frequently encountered in other groups of Hadzioidea, including the closely related genus Allomelita and the more distant outgroup Abludomelita. The Pseudoniphargus group is char- 


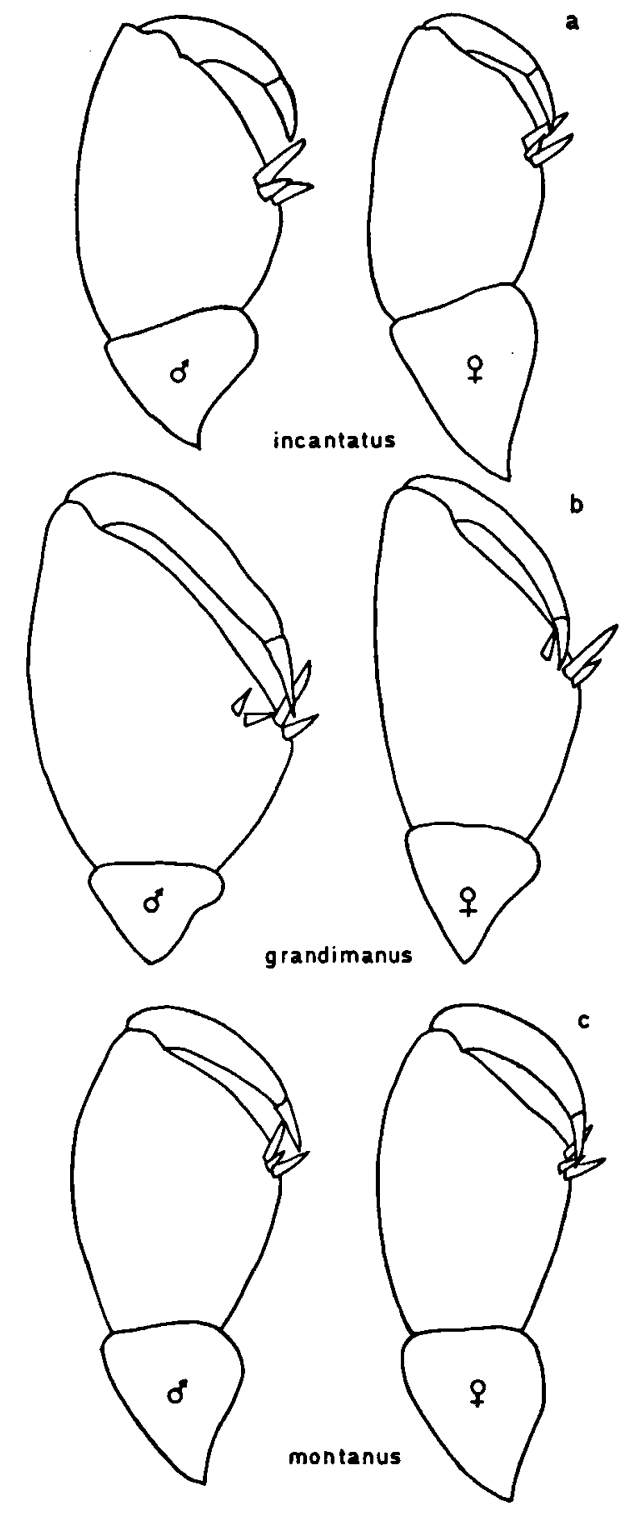

Fig. 14. Sexual dimorphism in the 2nd gnathopod of Pseudoniphargus (character 28).

acterized by a manifestly reduced sexual differentiation in the 2nd gnathopod (character 14.1). In Parapseudoniphargus there are no sexual differences at all, while in Pseudoniphargus the dimorphism is variously reduced. The condition in which there is an often very slight proportional difference in shape of the propodus between the sexes is considered apomorphous in Pseudoniphargus. The lack of sufficient material of both sexes renders a determination of the degree of sexual differentiation in $P$. eborarius and $P$. jereanus impossible. Congruence of character state distribution between these two species, and between $P$. burgensis and $P$. gorbeanus points to a corresponding condition of this character.

\section{Pereiopods}

The depth of the coxal plates shows interesting differences between groups of species. The general tendency is that many of the species of southern Spain have shallow coxal plates and most of the remaining species have plates of a medium depth. The ratio between depth and width of coxal plate 3 is taken as a measure for the depth of the plates (character 25). Plate 3 has subparallel margins and is, therefore, more accurately measurable than the other coxal plates. To avoid the influence of sexual differences, although hardly noticeable, only males have been used to calculate this ratio. Coxal plates of a medium depth ( $\geq 1.77$ times as deep as wide) are found in the outgroups of Pseudoniphargus and, therefore, considered to represent the plesiomorphous condition.

An additional character also related to the coxal plates used in the present study is the depth of the posterior excavation of plate 4 (figs. $4 \& 15$; character 26). The relative depth of the excavation is defined by the maximum width of the plate minus the minimum plate width divided by the length of the coxal plate. In Allomelita and Parapseudoniphargus, plate $\mathbf{4}$ shows a well-developed posterior emargination (ratio $>>0.16$ ), a condition assumed to be plesiomorphous.

An important diagnostic feature in Pseudoniphargus is the shape of the basis of the posterior pereiopods, in particular of pereiopod 7 (fig. 16; character 30). The general appearance of the basis is strongly influenced by its relative length, but above all by the degree of extension of the posterior lobe. An extended posterior lobe has the posterodistal corner more or less projecting and renders the basis oval or ovoid in shape. When the posterior lobe is not or just poorly developed, the basis is rectangular or somewhat linear with rather straight margins. 


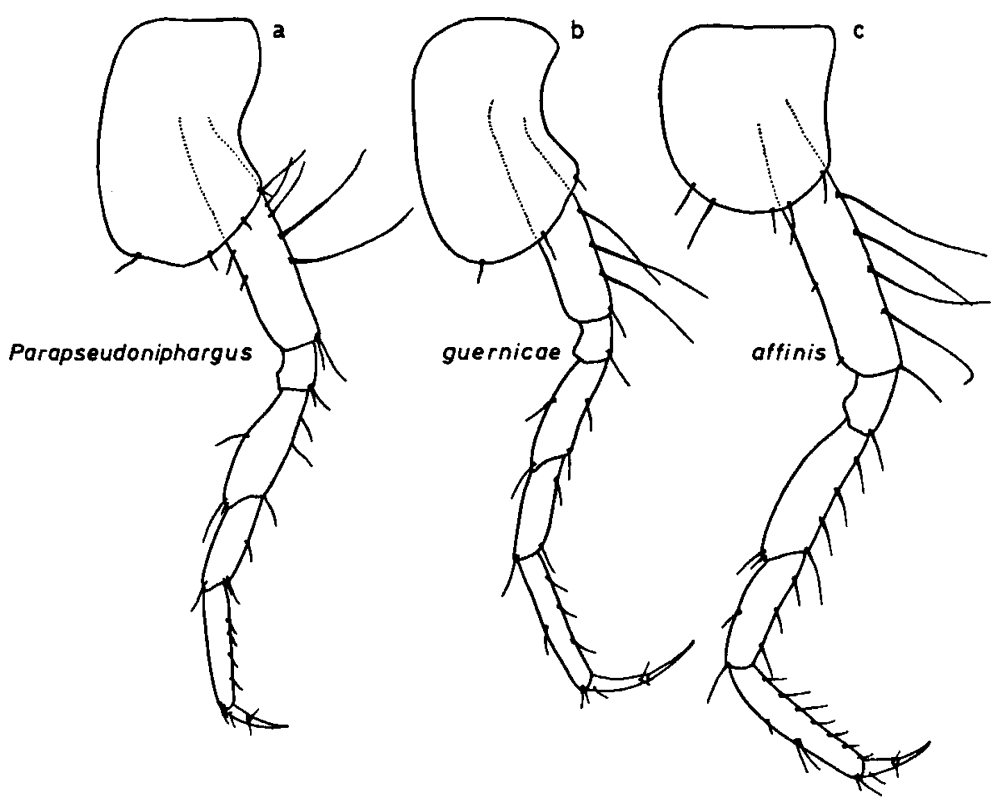

Fig. 15. Examples of the pereiopod 4 morphology in Pseudoniphargus and Parapseudoniphargus. The posterior emargination of the coxal plate (character 26) is distinct in a and b, very shallow in c. The claw (character 29) is slender in b, rather short in a and c. Parapseudoniphargus, the sister group of Pseudoniphargus, represents the plesiomorphous condition.

In species with an oval or ovoid basis the posterior lobe is always somewhat extended but the degree may vary among individuals. The extremes of the manifestation of this character can be recognized clearly. However, the condition of this character is difficult to ascertain in some intermediate forms, e.g., in $P$. margalefi (Notenboom, 1987a: fig. 21f). Outgroup comparison shows that the extended and oval type basis is found in closely related taxa (see fig. 16a of Parapseudoniphargus) and henceforth assumed to be the plesiomorphous condition. Species with an extended posterior lobe of the basis of pereiopod 7 have a broadly convex distal margin of the posterodistal corner. Pseudoniphargus adriaticus deviates from this by having a narrow and more or less rectangular projecting posterodistal corner, a feature which may be regarded an autapomorphy. The claw of pereiopod 7 provides two other quantitative characters, viz., the relative lengths of dactylus (character 31), and unguis (character 32); see fig. 17.

\section{Epimera}

The ventral margin of epimeral plate 3 bears a number of short spines, which is a very constant feature within species of the genus. In a number of species from northern Spain (e.g., $P$. burgensis, $P$. gorbeanus, $P$. incantatus) the ventral armature on epimeral plate 3 is totally lacking. Both in Allomelita and Parapseudoniphargus, and also in a large number of Pseudoniphargus species, 1 or 2 ventral spines are found, whereas in the two Bermudian species and the Azoran $P$. brevipedunculatus 3 or more of these spines are present. Two character transformation series are presumed to start from the plesiomorphous condition of 1 or 2 spines found in the outgroups. One development leads to the reduction of these spines and the other one to an increase in the number of spines (character $34)$.

The shape of the posteroventral corner of epimeral plate 3 fluctuates between rounded and rectangular, with a small tooth in most of 


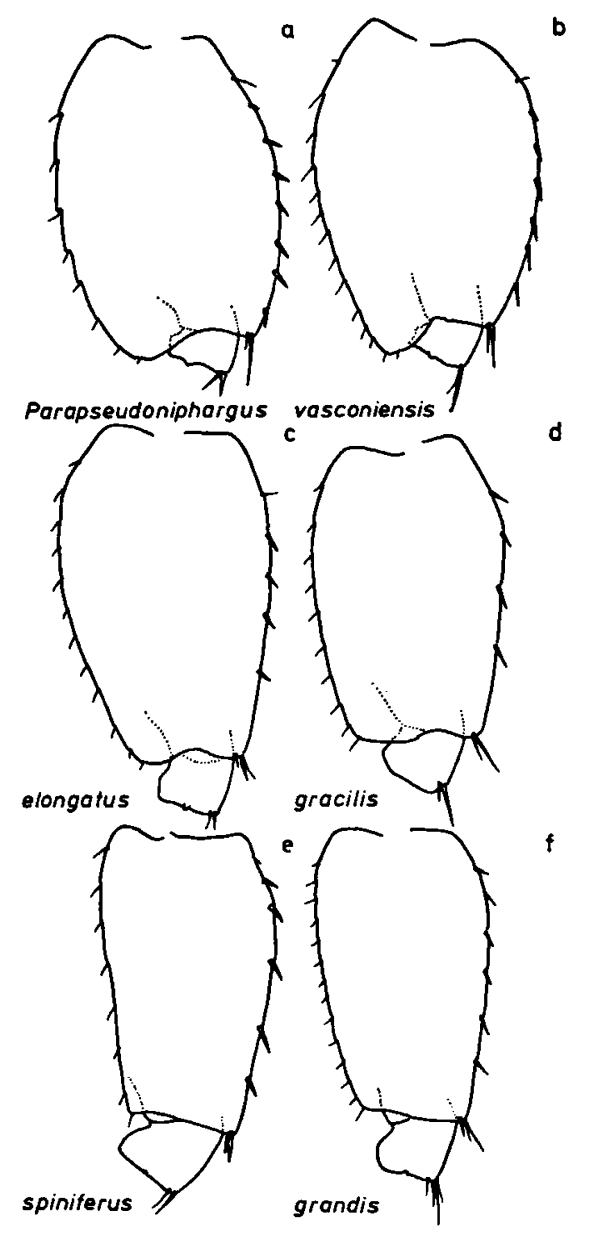

Fig. 16. Examples of the morphology of the basis of pereiopod 7 in Pseudoniphargus and Parapseudoniphargus. The posterior lobe (character 30 ) is expanded in a to d, poorly developed in e and f. Parapseudoniphargus, the sister group of Pseudoniphargus, represents the plesiomorphous condition.

the species of Pseudoniphargus, and in Allomelita and Parapseudoniphargus. The typically projecting, posteroventral corner (fig. 7) of $P$. vomeratus and $P$. illustris clearly deviates from the basic pattern and is considered an apomorphy (character 33). P. nevadensis is a problem case, because the posteroventral corner was found to be projecting in some but not all specimens studied.

\section{Uropods}

The third uropod forms one of the most aberrant morphological features of Pseudoniphargus.

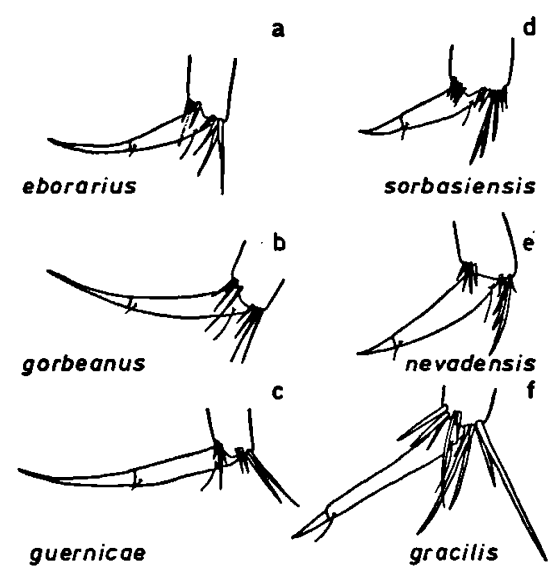

Fig. 17. Configurations of the claw of pereiopod 7 in Pseudoniphargus. Successive elongation of the dactylus (character 31) is seen from a to $c$, and from $d$ to $f$. The unguis (character 32 ) is relatively long in a-c, short in d-f. A situation comparable with $P$. eborarius is found in Parapseudoniphargus, the sister group of Pseudoniphargus, and considered to represent the ancestral condition.

A large number of the characters used in previous attempts to resolve the phylogenetic relationships within Pseudoniphargus were derived from this structural complex (Stock, 1980a; Boutin \& Coineau, 1988). On the basis of the appearance of the male and female uropod 3 among the species of the genus, a morphocline can be easily recognized (fig. 18). At the one end of the cline the third uropod is short, with along its margins a few distinct groups of rather strong spines which are similar in both sexes. At the other end the female and male uropods are dissimilar, exceedingly elongate in the male (involving both the peduncle and the exopodite), and only moderately so in the female. Intermediate arrangements between the extremes of the morphocline are encountered in which the female uropod is not elongate but in which the male peduncle and exopodite successively become elongate. In general the changes occurring in the male along this morphocline are explicit and more easily recognizable than the changes in the female. The elongation of the male exopodite is attained by changes in the configuration of the spines. The subadult male 3 rd uropod of a species which exhibits an exopodite elongation 


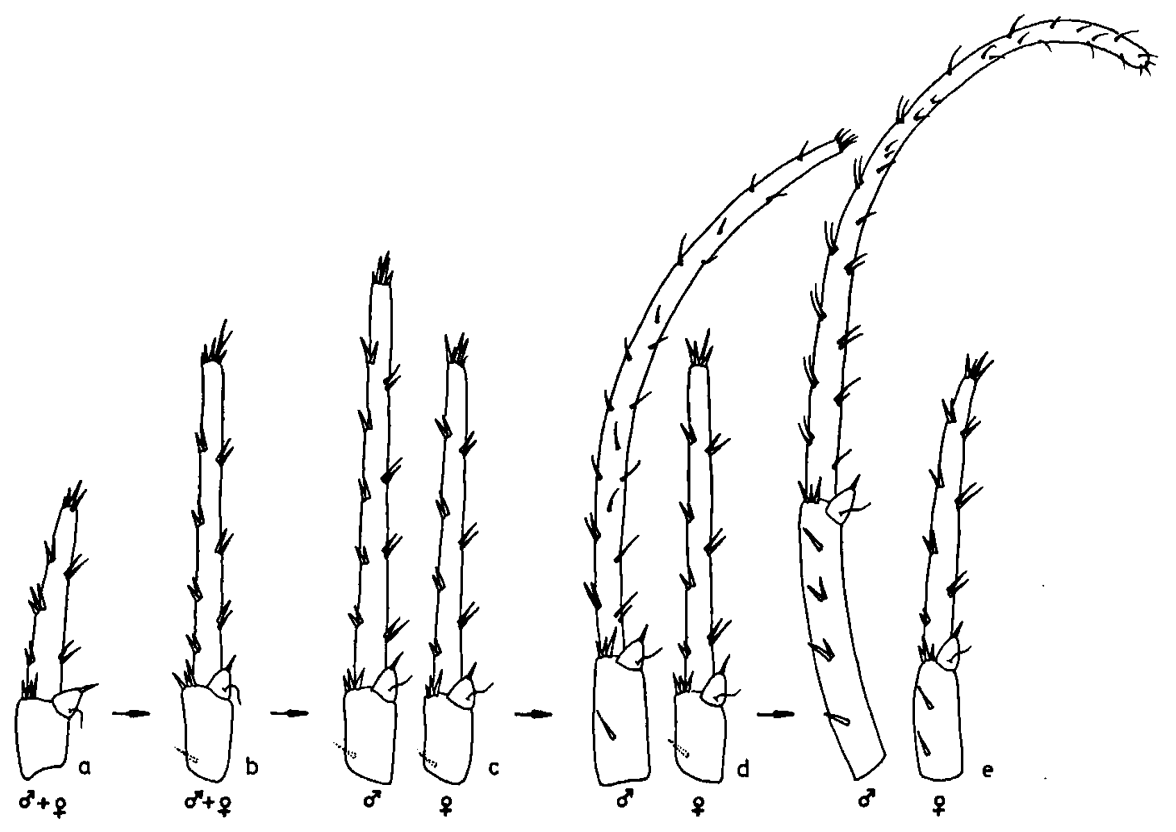

Fig. 18. Schematic representation of the 3rd uropod morphocline in Pseudoniphargus. From a to e the relative lengths of peduncle and exopodite increase. Sexual differentiation (character 38) is shown in c. Strong elongation of the male exopodite (character 42) starts at $\mathrm{d}$, while the peduncle (character 41) becomes strongly elongate in e. Dotted spines of the peduncle are not always present.

in the adults resembles those species in which no elongation occurs, this likewise by the presence of some groups of spines along the margins of the exopodite. When the uropod elongates during successive moults, a process which continues after maturity, the rather strong marginal spines gradually disappear and the exopodite becomes covered with irregularly placed small, slender spines. During this process the male uropod becomes typically upcurved, very strikingly so in senescent adults. In females of a species with a strong elongation in the male, the third uropod elongates as well, but without a rearrangement and transformation of spines, and without the development of a curvature. The polarity of the morphocline is easily ascertainable, since in the outgroups the third uropods are neither sexually differentiated nor elongate, which, accordingly, represents the plesiomorphous condition.

Four different characters are recognized within the third uropod morphocline: sexual differentiation (character 38), elongation of the male peduncle (character 41), elongation of the male exopodite (character 42), and presence of marginal spines on the peduncle (character 40). Stock (1980a) and Boutin \& Coineau (1988) used another character related to this morphocline, namely: female 3rd uropod modified versus not modified. This character is not used in the present study owing to the difficulty to decide whether a female uropod 3 is modified (elongate) or not. The elongation of the 3rd uropod appears to be a troglomorphic character, whose acquisition has an (obscure) relation with the hypogean mode of life of the animals. Independently evolved trends are seen within the Eriopisa complex, in Galapsiellus and in more distantly related genera such as Niphargus and Rhipidogammarus. Epigean amphipods showing such a development are not known. Superficially the elongated uropod 3 of Pseudoniphargus resembles that of Niphargus most (hence the name pseudo-Niphargus). However, in Niphargus only the exopodite, which is two- 
segmented, is involved in the process of elongation. This, as in Pseudoniphargus, results in a strongly elongated and upcurved uropod in senescent males of certain species.

An additional character of the 3rd uropod is the shape of the male exopodite (character 39). Most frequently, the margins of the exopodite of uropod 3 are subparallel, even in species with a strongly elongate exopodite. However, in a few species in which the male uropod is not extremely elongate, the exopodite is found to be clearly tapering. The difference between the tapering and the subparallel-sided exopodites is slight but unmistakable and best seen when this appendage is observed under a dissection microscope. On the photograph of $P$. grandimanus in Stock et al. (1986: fig. 2), the clearly tapering exopodite is well depicted. The condition of this character in Parapseudoniphargus is difficult to ascertain because this genus has a pygidized exopodite. In Allomelita the margins of the exopodite are subparallel. The subparallel condition of the exopodite is tentatively assumed to be plesiomorphous.

Telson

The telson shows a rather large variation in Pseudoniphargus; four characters associated with this structure are distinguished: the position of the distal spines (character 43), the number of distal spines (character 46), the sexual differentiation in the shape of the telson (character 45), and the shape and depth of the distal emargination (character 44). The telson is distally bilobed, usually with a wider or smaller, yet rather shallow emargination, but in a few species without emargination, and in a group of North-Spanish species and $P$. brevipedunculatus with a relatively deep and sharply $V$-shaped emargination. Each telson lobe bears a number of spines either implanted on the distal margin at the tip of the lobe or subapically implanted, so that the tips of the lobes are unarmed. In a number of species with an only slightly emarginated telson it is more or less obscure whether these spines are subapically implanted or not. Two classes of numbers of spines on either telson half are distinguished (character
46): one with 2 spines per telson half (sometimes 3 spines on one side only) and the other one with 3 or more spines per half. In the latter class changes to more than 5 spines per telson half are gradual and no subdivision could be made. Whether the densely spinous or sparsely spinous telson is the plesiomorphous condition is difficult to ascertain, since both conditions obtain in the immediate outgroups. In most species of Pseudoniphargus and in closely related outgroups the shape of the telson is basically similar in both sexes, with the exception of $P$. vomeratus and $P$. illustris, in which species the males have a telson that is longer than wide and distinctly longer than it is in the females. This character appears to be a synapomorphy in these two species.

\section{Cuticula}

In some selected species of Pseudoniphargus and in Allomelita and Parapseudoniphargus the cuticular microstructures were examined with SEM. The selected samples of Pseudoniphargus originated from different groups of closely similar species distributed over the entire range of the species under study. In general the submicroscopical features examined (morphology of pores, arrangement of pores, and morphology of different types of microtrichs) are very uniform. The most conspicuous deviation concerns the arrangements of pores on pereionite 1 (character 47). In Parapseudoniphargus and nearly all species of Pseudoniphargus the micropores are randomly scattered over the entire area of the polygones (fig. 8), but in $P$. montanus and in $P$. longicarpus a different configuration is encountered, the pores abutting against one another to form distinct rows (fig. 9). The latter feature has not been found in any other species examined and is, therefore, considered to be apomorphous.

\subsection{Numerical phylogenetic analysis}

The monophyletic groups and their synapomorphies supported by compatibility analysis are listed in table VIII. The compatibility analysis results in a collection of largest cliques 
comprising 11 character states. Eight of these character states are in the intersection of the largest cliques (underlined in table VIII), and 5 other states are included in alternating combinations (not underlined in table VIII). The 15 remaining character states fall beyond every largest clique. These strongly incompatible characters comprise a relatively large number of the quantitative ones. As in the outgroup analysis, the number of potential apomorphies (32) is insufficient to resolve phylogenetic relationships between the species of Pseudoniphargus. Compatibility analysis shows that the inconsistency in the data is substantial.

Parsimony cladograms were construed with unweighed and weighed characters according to the Wagner and Camin-Sokal methods. Weighing of characters has been expressed by giving all compatible characters (table VIII) a double weight. Both methods yield rather large numbers of equally parsimonious cladograms.

\section{TABLE VIII}

Monophyletic groups and their synapomorphies found by means of a compatibility method in ingroup analysis. Underlined are characters present in the intersection of all largest cliques. Note that there is an internal discrepancy as regards the monophyletic groups based on characters (non-underlined) not present in the intersection of all largest cliques.

Monophyletic group

Synapomorphous characters

(cf. table VI)

1. burgensis, eborarius, gorbeanus, guernicae, incantatus, jereanus, vasconiensis

2. $1+$ unisexualis

3. carpalis, grandimanus

4. 3 + callaicus

5. $3+$ brevipedunculatus

6. $4+$ brevipedunculatus, gibraltaricus, mateusorum

7. longicarpus, montanus

8. vomeratus, illustris

9. affinis, elongatus, granadensis, grandis, stocki

10. $8+9+$ adriaticus

11. $10+$ branchiatus, nevadensis

12. $11+$ brevipedunculatus, fragilis

13. all taxa, but latipes
Strict consensus cladograms of the most parsimonious solutions are presented in figs. 19 \& 20; the indicated synapomorphies match all solutions. The Wagner cladograms require fewer evolutionary steps than the Camin-Sokal cladograms. Thus, by permitting character reversals, the total number of homoplasies decreases. The highest consistency indexes in the Wagner cladograms are 0.4432 (weighed characters) and 0.3889 (unweighed characters), in the Camin-Sokal cladograms these values are 0.3611 and 0.3294 , respectively. Weighing of compatible characters caused an increase in consistency of the results arrived at by both parsimony methods. Evidently, many species remain ungrouped and support has been found for only a limited number of monophyletic groups.

The largest group of species evidenced by synapomorphies on which there is also agreement between the different methods applied, is a cluster of species from Burgos and Basque Country (northern Spain). This assemblage, named the "Burgo-Vasconia group" (group 1 in table VIII), has $P$. unisexualis as its probable sister group, whose distribution falls within the range of that group. Other well-corroborated monophyletic groups on which the different methods agree, consist of sister species only. They comprise the "Cantabrian group" ( $P$. longicarpus and $P$. montanus) distributed in the western Cantabrian Mountains of northern Spain, the "Bermuda group" ( $P$. carpalis and $P$. grandimanus), and $P$. illustris and $P$. vomeratus, found in the central Betics of southern Spain.

There is some weak evidence for the validity of the groups which do not emerge after all numerical approaches. The synapomorphies of these groups are weak by being defined by mostly homoplasous characters. Two rather large groups belong to this category: the first, consisting of $P$. carpalis and $P$. grandimanus from the Bermuda group supplemented by the other species from the Lusitanian-Atlantic region. The members of this Lusitanian-Atlantic group share a strongly compatible character (viz., character 39). There is, however, an internal conflict through which the group does not 

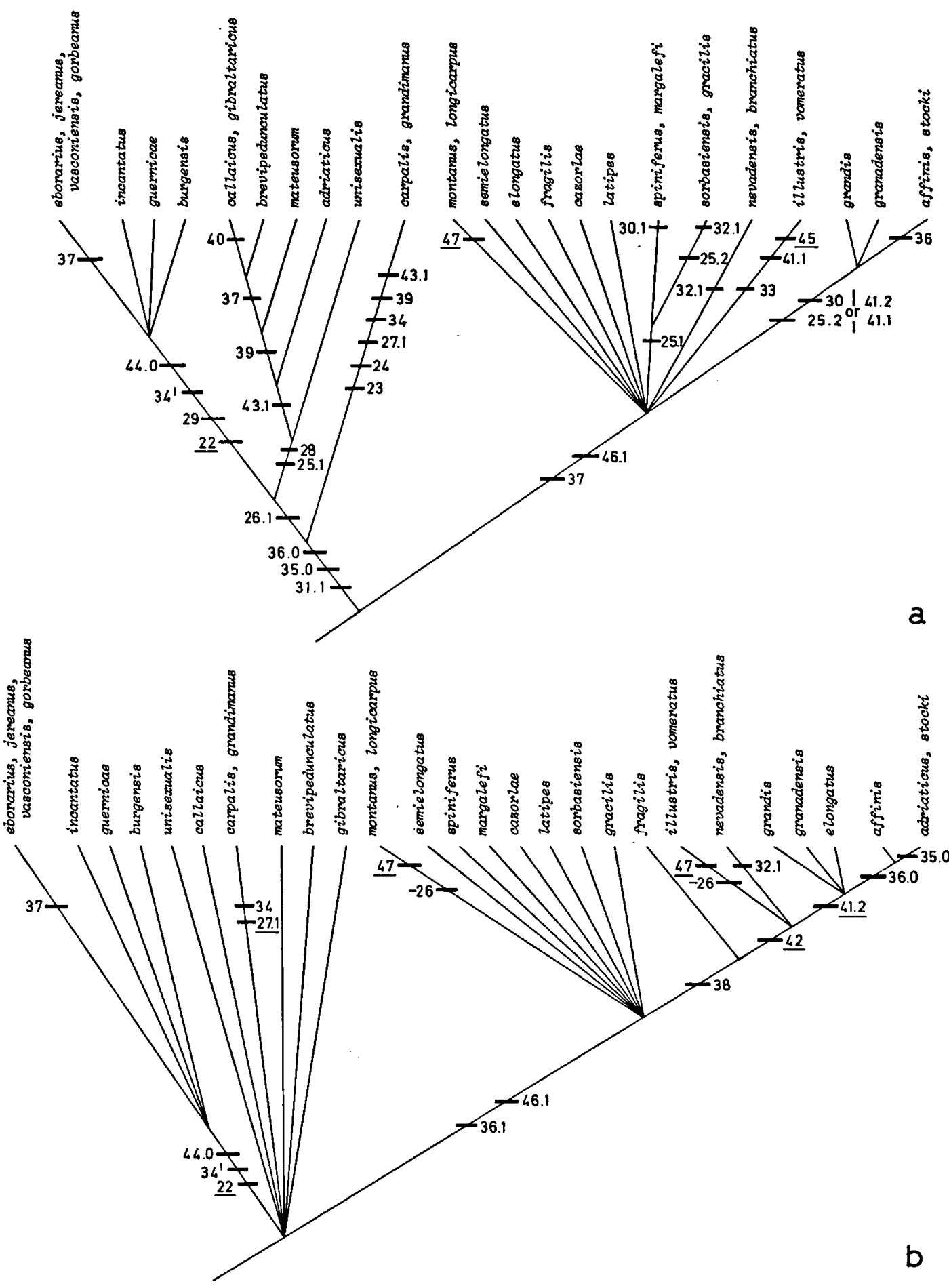

Fig. 19. Consensus cladograms of ingroup analysis of Pseudoniphargus with unweighed characters, matching synapomorphies indicated, uniquely derived characters underlined, and reversals indicated by minus sign: a, cladograms construed with Camin-Sokal parsimony method; b, cladograms construed with Wagner parsimony method. 


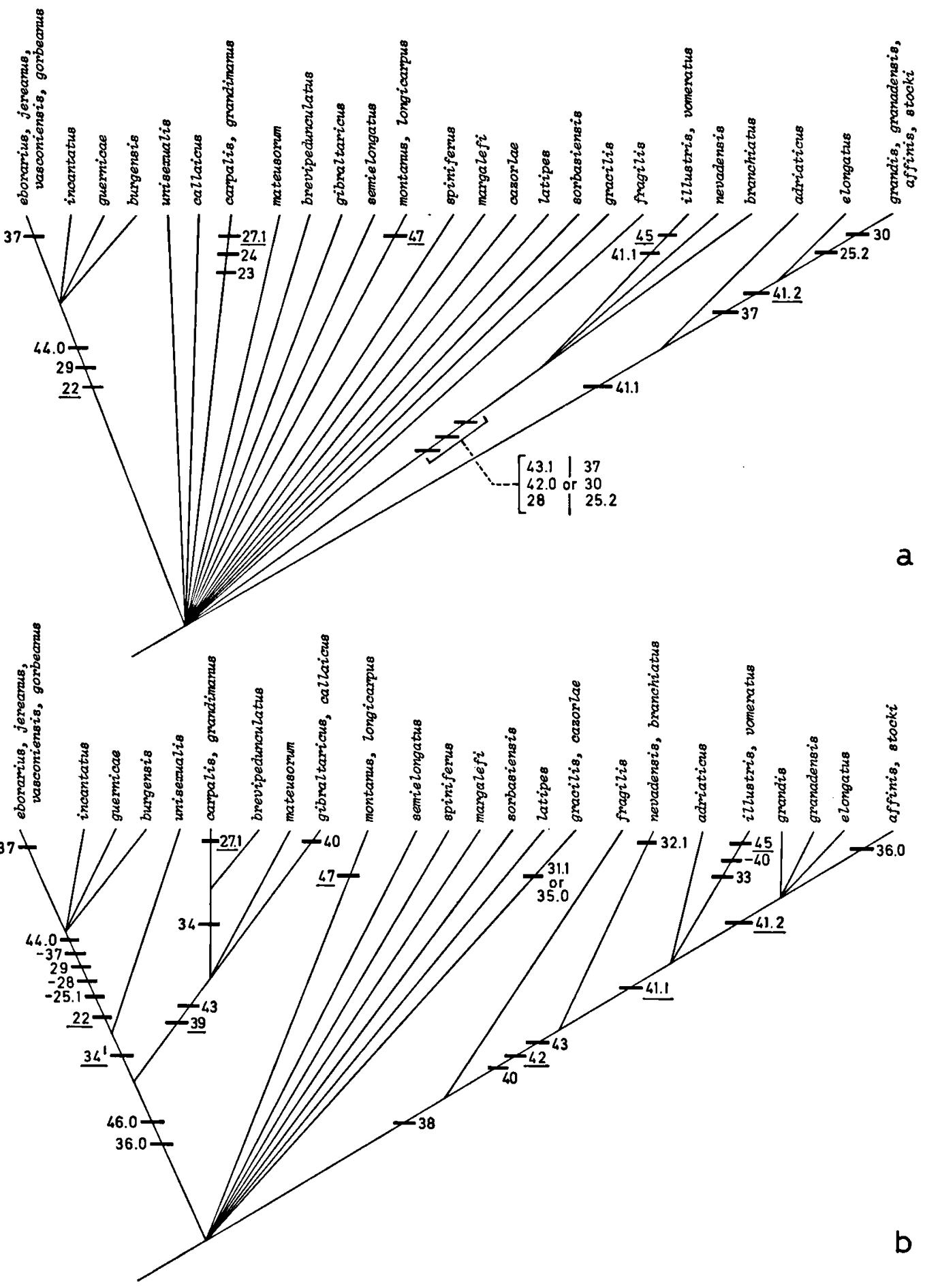

Fig. 20. Consensus cladograms of ingroup analysis of Pseudoniphargus with weighed characters, matching synapomorphies indicated and uniquely derived characters underlined: a, cladograms construed with Camin-Sokal parsimony method; b, cladograms construed with Wagner parsimony method. 
emerge in all parsimony solutions. The second, a group containing all species from southern Spain that possess a modified 3rd uropod, supplemented by $P$. elongatus from northern Spain and $P$. adriaticus from the northern Mediterranean belt (the $P$. branchiatus group). This group emerges in both Wagner parsimony solutions and is mainly characterized by the strongly compatible elongation of the exopodite of male uropod 3 (character 42). The $P$. branchiatus group comprises those species of the genus that possess the largest percentage of apomorphous characters. When the autapomorphies of table $\mathrm{V}$ and the polarized characters of table VII are chosen, this percentage is $23-34 \%$ in the $P$. branchiatus group against $9-27 \%$ in the other species of the genus.

The monophyletic groups of Pseudoniphargus, whether they are strongly or weakly corroborated, are for the greater part geographically related, which appears to provide additional evidence for the validity of these groups (fig. 22). The Lusitanian-Atlantic group is of great biogeographical interest owing to its wide distribution on Atlantic oceanic islands. The Burgo-Vasconia and Cantabrian groups are well founded and their ranges appear to be confined to geologically and geographically clearly separated entities of the CantabrianPyrenean mountain complex. With the exception of $P$. elongatus and $P$. adriaticus, the $P$. branchiatus group is restricted to the Betic Cordillera with the well-established subset of $P$. vomeratus and $P$. illustris in the central Betics. The geographical ranges of the $P$. branchiatus group and of the Mediterranean $P$. adriaticus are adjacent, and both are clearly separated from the North-Spanish range of $P$. elongatus.

The Algerian P. macrotelsonis Stock, 1980 possesses a strongly elongated male 3rd uropod, projecting posteroventral corners of the epimeral plates, and a sexually dimorphic

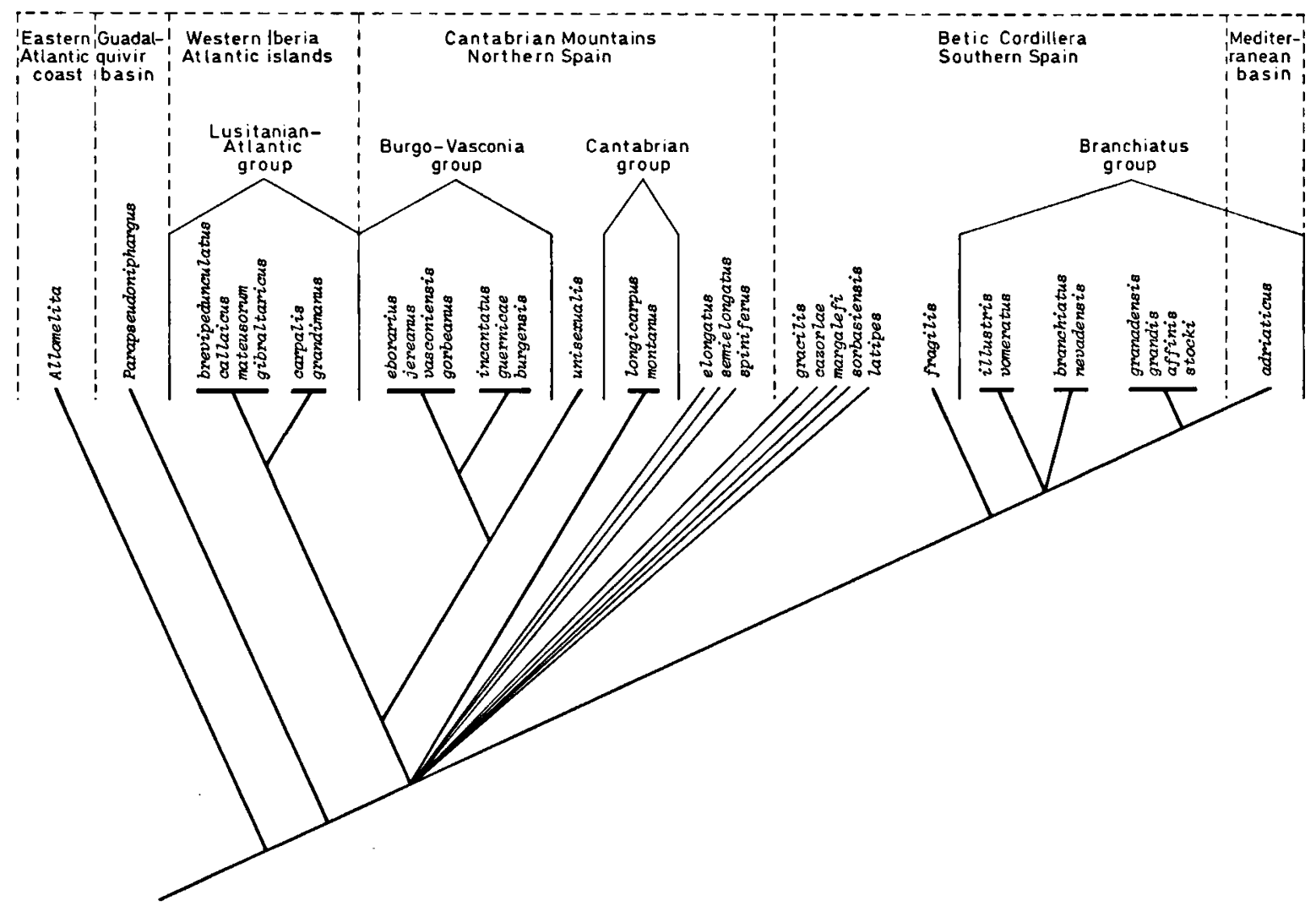

Fig. 21. Proposed phylogenetic tree of Pseudoniphargus. 
telson. These are features through which this species may be related to $P$. vomeratus and $P$. illustris of the $P$. branchiatus group. The other Algerian species, $P$. africanus Chevreux, 1901, resembles the members of the $P$. branchiatus group in the elongated male 3 rd uropod character, but clearly differs by the expanded basis of the posterior pereiopods.

Probably the best estimation of phylogenetic relationships within Pseudoniphargus, based on an integration of the different numerical methods, is given in fig. 21. In this scheme $P$. elongatus is independently evolved from the geographically coherent $P$. branchiatus group according to the unweighed Camin-Sokal parsimony solutions (fig. 19a). This is plausible because in view of the large distance between their ranges it is most unlikely that these groups share a common ancestor. Moreover, $P$. elongatus lacks two apomorphies well represented in the $P$. branchiatus group and in other species from southern Spain, viz., the shallow coxal plate 3 (character 25.2) and the weakly developed posterior lobe of the basis of pereiopod 7 (character 30.1). In the proposed phylogenetic tree (fig. 21) a strong elongation of the male 3rd uropod took place in two independent lineages and, consequently, the condition of this character in $P$. elongatus is not homologous with that in the $P$. branchiatus group.

\subsection{Diagnosis of monophyletic groups of Pseudo- niphargus}

Burgo-Vasconia group.- Setal groups on terminal peduncle and proximal flagellum segements of antenna 2 including many setae exceeding the width of the segments. Sexual differentiation in shape of propodus gnathopod 2 well developed; palmar margin in male more oblique than in female. Coxal plates deep, with plate 4 variously emarginated posteriorly. Claws of pereiopods 3 and 4 strongly elongated. Basis of posterior pereiopods expanded with overhanging posterodistal angle. Ventral margin of epimeral plates devoid of spines. Medial spines on peduncle of uropod 1 absent. Uropod 3 short, without sexual dimorphism. Emargination of telson sharply Vshaped. Members: P. burgensis, eborarius, gorbeanus guernicae, incantatus, jereanus, and vasconiensis.
Cantabrian group.- Sexual dimorphism in gnathopods absent. Tendency to elongation of carpus in gnathopods 1 and 2. Coxal plates deep, posterior emargination of plate 4 pronounced. Basis of posterior pereiopods expanded with overhanging posterodistal angle. Epimeral plates with 1-2 ventral spines. Medial margin of peduncle of uropod 1 provided with spines, the rami with marginal spines. Uropod 3 short, not sexually dimorphic. Telson with 3 or more spines on each half, distal emargination shallow. Small cuticular pores forming distinct rows. Epidermal cells with rows of pores irregularly distributed over the body. Members: $P$. longicarpus and montanus.

Lusitanian-Atlantic group.- Mandible palp in some species with a longer group of proximal D-setae. Inner lobe of maxilla 1 with up to 3 setae. Sexual dimorphism in gnathopod 2 weakly developed. Coxal plates deep, plate 4 hardly emarginate posteriorly. Basis of posterior pereiopods expanded with overhanging posterodistal lobe. Epimeral plates with ventral spines. Medial spine on peduncle of uropod 1 absent or poorly developed. Rami of uropods 1 and 2 slender and without marginal armature. Sexual dimorphism in uropod 3 not or only weakly developed. Exopodite of uropod 3 tapering and not strongly elongate in male. Telson with $2(-3)$ subapically implanted spines on either side. Members: $P$. brevipedunculatus, callaicus, gibraltaricus, mateusorum, carpalis, and grandimanus.

Note: The sister species $P$. carpalis and grandimanus (Bermuda sub-group) are characterized by the following features: mandible palp with small group of longer proximal D-setae; carpus of gnathopod 1 tending to elongate strongly; propodus of gnathopod 2 may be sexually differentiated in shape; ventral margin of coxal plates 3 and 4 strongly setose; ventral margin of epimeral plates with numerous spines (more than 3 on plate 3 ).

$P$. branchiatus g rou p. - Sexual dimorphism in gnathopods weakly developed. Carpus of gnathopod 1 tending to elongate. Unguis of gnathopod 2 very short. Coxal plates of medium depth, posterior emargination of plate 4 very shallow or none. Basis of posterior pereiopods narrow, without overhanging posterodistal angle. Epimeral plates with 1-2 ventral spines, in some species posteroventral corners projecting. Peduncle of uropod 1 well beset with medial and dorsal spines. Uropod 3 sexually dimorphic, peduncle and exopodite in the male strongly elongated and upcurved. Telson richly spinous in most species. Members: $P$. branchiatus, nevadensis, granadensis, grandis, illustris, vomeratus, stocki, affinis, and adriaticus. Uncertain: $P$. elongatus.

Note: The sister species $P$. illustris and vomeratus are characterized by projecting posteroventral corners of the epimeral plates, and a sexually dimorphic telson. 


\section{DISCUSSION OF PHYLOGENETIC RESULTS}

\subsection{Character incompatibility and unresolved relationships}

The results of numerical outgroup and ingroup analyses of Pseudoniphargus show largely unresolved phylogenetic relationships and but little agreement between the different methods applied. The results suffer from: (1) the insufficient number of potential apomorphies available to resolve phylogenetic relationships at the species level, and (2) the many inconsistencies in the data. A good few taxa could not be arranged into monophyletic groups and the majority of the monophyletic groups emerged are defined by few (often only a single), rather weak synapomorphies, rendering the results of the analyses insufficiently convincing. The outgroup analysis is partly based on overall similarity between a number of hadzioid amphipod taxa. Within this cluster of presumedly interrelated taxa, but of unknown phylogenetic origin, the group AllomelitaParapseudoniphargus-Pseudoniphargus seems to be a well-established, monophyletic subset.

Ingroup analysis did not yield one single phylogenetic assessment of Pseudoniphargus species. The consensus of many equivalent cladograms is a largely polychotomous structure with some of the branches containing single individual species and other ones monophyletic groups of species. The low numbers of potential synapomorphies and the large inconsistency in the data might be attributable to either the underlying evolutionary process, or the universal problems of phylogenetic reconstruction at low taxonomic level. There are undoubtedly weaknesses in the data sets conceivably responsible for the unequivocal results of the analyses, but it must be emphasized that not every mode of speciation will lead to a "neat" pattern of dichotomous relationships. For example, Wiley (1981: 48) gives an allopatric speciation model with peripheral isolates around the range of a single ancestral species (peripatric speciation sensu Mayr, 1982). The descendent species will share only the common character also shared by the ancestral species and all other peripheral isolates, and the pattern of descent as evidenced by synapomorphies is expected to be polychotomous.

The members of the groups which emerge after parsimony analyses share two types of apomorphies. The first type comprises evident synapomorphies that are strongly compatible characters and are shared only by the members of the group. These characters are underlined in the consensus cladograms of the parsimony analyses (figs. 12, $19 \& 20$ ). The second type includes the weak synapomorphous characters (not underlined) that are considered to be homologous among the members of the group for which they serve as a synapomorphy, but which characters are derived independently in species not belonging to the group. In the consensus cladograms, weak synapomorphies are mostly shown on a single branch only. This means that the homoplasous condition may be an autapomorphy, which is not shown, or that there is no consensus regarding the other place(s) in the cladogram where the character is apparently derived. Weak synapomorphies are mostly incompatible as characters and have only a restricted, local significance. Their appearance in the diagrams depends entirely on parsimony decisions in which all characters are involved. An addition or removal of characters may have a substantial effect on the appearance of homoplasous similarities as synapomorphies among a certain group in the parsimonious cladograms.

Special problems encountered when cladistic analyses are applied at low taxonomic levels have been discussed by Arnold (1981). These problems may arise from the situation rather than from the method and it remains to be seen whether other approaches will yield better results. Several points discussed by Arnold (1981) seem to be relevant to the present study. At a low taxonomic level, species share similar gene pools, so that true parallelisms are likely to occur. Moreover, as is also the case in Pseudoniphargus, the available characters tend to be simple, which renders homoplasies difficult 
to detect, a possible polarity less easily assessable, and reversals more likely to occur. In addition, polymorphism frequently increases errors made in the selection of appropriate character states to be used in the analysis. At a low taxonomic level there is usually a shortage of usable characters, with the consequence that errors made in the recognition of synapomorphies have a proportionally large influence on the ultimate result.

The large number of evolutionary steps in all equally parsimonious cladograms renders a reconsideration of the validity of postulated phylogenetic characters obligatory. The question arising is whether the character states are indeed mutually exclusive homologues. The morphological criterion of homology applied in this study is that of similarity of position (homotopy) and connection with other body parts. Undoubtedly all topographically similar articles of appendages are homologous, but it is less self-evident that very similar kinds of ornamentation with spines or setae found on structures in corresponding topographic positions, or comparable proportions of these structures, constitute homologous characters. The problem is that precise chaetotaxic data and relative changes in the proportion of articles are almost the only available information in amphipod studies, in particular at low taxonomic level, and that presumptions of homology of this kind of character are difficult to put to the test. Therefore, many of the characters are suspect and it is not surprising that the cladograms show a large amount of homoplasy in many characters.

The statistic unreliability of the quantitative characters is appreciable, but inevitable in view of the very small sample sizes in most cases. The use of counts or ratios as quantitative characters in this study has two reasons: (1) to avoid subjective character state definitions (such as short vs. long, slender vs. broad, many vs. few); (2) to search for non-overlapping ranges in observations along clearly recognizable morphoclines. Moreover, it has to be stressed that only very few characters are available in Pseudoniphargus. Therefore, quantitative data are not a priori neglected, notwithstanding the valid objections against the use of this kind of information in phylogenetic studies owing to the difficulties encountered when testing their homology (Pimentel \& Riggins, 1987).

\subsection{Hypogean features as complicating factors in phylogenetic analysis}

All species of Pseudoniphargus and many taxa used in the outgroup analysis are adapted to a hypogean way of life. Taxonomically diverse groups of animals adapted to subterranean modes of life, such as many groups of crustaceans (not only amphipods), insects, arachnids, and other ones, show similar, "cave". dependent ("cave" used here as a term of convenience for subterranean, aquatic and terrestrial habitats in general) morphological modifications (Vandel, 1965; Barr, 1968; Ginet \& Decou, 1977; Culver, 1982). These modifications, often referred to as structural reductions (through regressive evolution) and as troglomorphic characters (Culver \& Fong, 1986), are of general occurrence and connected with the adaptation and speciation of "cave" animals.

Typical, structural reductions are the loss of eyes and body pigment, the reduced setation of cephalic and thoracic appendages, and the reduced coxal plates and pleopods, characters found in several stygobiont amphipods (e.g., in ingolfiellids, bogidielloids, and hadzioids). Acquired troglomorphic characters include the lengthening of appendages, the increase in number and complexity of sense organs, and the general appearance of fragility. However, little is known about the functional model (sensu Dahl, 1976) of stygobiont amphipods in relation to the environmental characteristics of the hypogean realm and the importance of structural reductions and troglomorphic characters in that model. Structural reductions and troglomorphic characters may play an important role in many of the character transformations in this study. This is most obvious in the eye reduction (character 2), the elongation of uropod 3 (characters $41 \& 42$ ), and the claws of 
pereiopods (characters 29, 31 \& 32), but is probably also responsible for reductions in the setation of cephalic appendages (characters 3, 5, 6 \& 7), the number and size of spines on the urosome (character 16), and the diminuation of the depth of coxal plates (character 25). It follows that very similar, "cave"-dependent features may easily have evolved in independent lineages, which in turn may result in character incompatibility.

After amphipods have hatched as miniature adults, their growth progresses by a series of moults, which separate the instars. Size increment occurs at each moult, and is often accompanied by changes in proportion (allometric growth). In general, the percentage of size increment per moult decreases and the intermoult period lengthens as the size of the animal increases (Hartnoll, 1985). In the stygobiont Niphargus virei, for example, adults of 2.5 years old moult twice a year, but 4 years old specimens only once (Turquin, 1984a). Apart from gradual changes in form, no distinct morphological features distinguish instars or series of instars from each other. The species of Pseudoniphargus may show, at least to a certain degree, extension of the duration of their life cycle. This phenomenon is observed in Niphargus and is common in many other stygobionts (Ginet, 1960; Henry, 1976; Magniez, 1976, 1978; Ginet \& Decou, 1977; Turquin, 1984b, Coineau, 1984). The morphology of the senescent and fully differentiated males of stygobiont amphipods may differ considerably from that of the young adult stage due to their remarkable longevity accompanied by allometric changes. Females apparently do not show such a pronounced senescent morphology.

During the taxonomic studies of Pseudoniphargus in some series of specimens a few larger adults were encountered with more pronounced morphological features than exhibited by the smaller mature specimens (setose oostegites or well-developed genital papillae present). In particular, the relative proportions of the carpus of the gnathopods, the propodus of the second gnathopod, the claw of the pereiopods, the basis of the posterior pereiopods, and the peduncle and exopodite of the third uropod show allometric changes. Altogether a complex of modifications leads to a distinct senescent morphology. Certainly not all species of Pseudoniphargus exhibit this allometry phenomenon. For instance, in the small species $P$. incantatus, of which much material is available, no conspicuously larger individuals with an abberrant morphology were found. Allometric differentiation appears to be of relatively large importance in the $P$. branchiatus group, which comprises rather large species showing a high rate of apomorphy.

One must bear in mind that differentiated, senescent adults are encountered in very small numbers, if present at all. In case the systematics of a group depends to a large extent on the morphology of senescent specimens, this creates an unworkable situation. Strictly speaking, in phylogenetic studies morphological comparisons between amphipods ought to be made between the same post-puberty instar phases (comparable semaphoronts), but this is not feasible and not always necessary because of insignificant differences between post-puberty instars. However, in case strong allometric changes take place, a morphological comparison between adult specimens of different developmental stage may cause misinterpretations in the character analysis. This problem is serious when allometric problems are not discernible in collected samples containing only a small number of specimens of a species, a problem often encountered in stygobiont amphipod studies.

The morphological differentiation between certain species probably occurs in a later stage of maturity and thus the older adult provides more diagnostic characters than the younger adult. On the other hand, it must be borne in mind that morphological changes affecting the aberrant senescent adult morphology probably involve only troglomorphic characters in relation to their evolution in subterranean habitats. As mentioned above, troglomorphic characters have only a restricted significance in phylogenetic studies. Ontogenetic information and 
allometric growth models (Kluge \& Strauss, 1985) may be promising methods to test the homology of such allometric, troglomorphic characters. These methods may be employed to test parallel evolution (for example of the elongation of uropod 3 , and of the claws of pereiopods) in Pseudoniphargus. However, in the present context allometric differentiation has not been studied specifically.

\subsection{Phylogenetic methodology}

The interpretation of phylogenetic relationships is based on an evaluation of the most parsimonious cladograms and the largest cliques of compatible characters. However, there is no reason to consider the most parsimonious solution or the largest clique to be a significantly better estimate of the true phylogeny than a somewhat less optimal solution (Felsenstein, 1985). The application of statistical methods to compute confidence limits for monophyletic groups, as provided by PHYLIP BOOT (Felsenstein, 1985, 1987), from results mostly based on only a few, often indistinct synapomorphies, is but little informative. A practical drawback is that run-times for the BOOT program are high in data sets with so many taxa involved. Nevertheless, the cladograms derived are the most probable the available data set can produce under the assumptions of the different parsimony methods. However, the small number of characters in the largest cliques found after compatibility analysis compel scepsis as regards the adequacy of the data set to provide a valid estimate of phylogenetic relationships (Meacham \& Estabrook, 1985).

Felsenstein (1984) stated that in case the rates of evolution are so low that all characters will be compatible, both parsimony and compatibility techniques may be expected to yield identical results. If the rates of evolution are slightly higher in all characters (which means that these characters more easily evolve convergently), a parsimony method will probably perform best, but if the rates of evolution are higher in a few characters and remain low in the remainder, a compatibility method is to be recommended. In our case it might be interesting to know if there are any differences in the rates of evolution between, for example, "cave"-dependent and "cave"-independent characters, but this kind of information is not available. If "cave" dependent characters often develop convergently, a situation might arise in which parsimony methods will be expected to be more consistent. Furthermore, Felsenstein (1984) remarked that, when rates of evolution differ dramatically from one lineage to another, both the parsimony and the compatibility methods may fail to be consistent, even with modest rates of evolution. In case the number of characters is low in comparison to the number of taxa, Sokal et al. (1984) suggested that phenetic techniques produce a better estimate of the true phylogeny than cladistic techniques (Conlan, 1988).

Stygobiont animals show adaptations to the abiotic and biotic conditions of the subterranean aquatic, mostly food-poor, habitats, and they cannot bear the abiotic and/or biotic circumstances at the surface. This makes the evolution of stygobiont species from surface, ancestral populations, a unidirectional process. Combining the evidence that the process of stygobiont adaptation and speciation is unidirectional and connected with the acquisition of "cave"-dependent characters, the conclusions may be drawn that the incidence of reversals in this group of characters is decidedly unlikely. An analysis of such characters by means of parsimony methods may, therefore, yield a better estimate from the Camin-Sokal method than from Wagner's. However, this produces less parsimonious cladograms as a consequence of the evolutionary process under study. We are in point of fact confronted with a mixture of "cave"- dependent and "cave". independent features and it is difficult to establish which of the two parsimony methods provides a better estimate of phylogenetic relationships.

The phylogenetic analysis of Pseudoniphargus has been carried out with the exclusion of the taxa from the Canary Islands and North Africa. 
This was done on the assumption that the exclusion of certain members of the group will not produce misleading interpretations (Arnold, 1981). However, Arnold sounds the warning that an omission of taxa, in particular at the low taxonomic level in situations where parallelism and unresolved polychotomies are relatively common, may cause misinterpretation. On the other hand, a phylogenetic analysis of the entire genus Pseudoniphargus does not appear to be meaningful when the number of qualitative phylogenetic characters remains relatively low and problems of homoplasy still predominate.

\section{ORIGIN OF PSEUDONIPHARGUS AND BIOGEOGRAPHY}

Pseudoniphargus exhibits a low degree of morphological differentiation, which may point either to a high rate of developmental homeostasis, or to a very low evolutionary progression. The small offspring produced by Pseudoniphargus may mean that little genetic material is available to the evolutionary mechanism and speciation progresses but slowly (Sterrer, 1973). Epiphenotypes tend to differentiate stochastically, which results in species characterized only by new combinations of features within the constraints of the developmental homeostasis. The external morphology does not support the idea of genetic differentiation in response to changing ecological conditions, and of colonization of new niches in parts of the original range of the ancestor. The concept of non-adaptive radiation seems to fit the Pseudoniphargus pattern better than that of adaptive radiation.

The species of Pseudoniphargus must have had a direct marine origin (it is a thalassoid group), as can be deduced from the following evidence: (1) the genus is related to the Hadzioidea, a group of amphipods whose epigean representatives are almost exclusively inhabitants of shallow-littoral, marine habitats; (2) the distribution of Pseudoniphargus closely corresponds with areas flooded by the epicontinen- tal seas during the Tertiary or exceptionally the Late Cretaceous; and (3) the genus still has representatives in brackish and marine groundwaters.

In zoogeographical studies the distribution of Pseudoniphargus and of many other stygobiont crustaceans (e.g., of Hadzia, Stygocyathura, and the Thermosbaenacea) is frequently referred to as a "Tethyan" pattern. The animals exhibiting such a distributional pattern are accordingly called "Tethyan elements". In such cases the term refers to the distribution of recent living organisms that falls within the limits of the ancient Tethys belt. Usually there is a rather close correlation between the distribution of Tethyan elements and areas covered by the shallow Tethys or its coastlines. It is further assumed that the progenitor of the Tethyan element was wide-spread in the Tethys sea or in a part of it. The continuity of the equatorial and (sub)tropical Tethys ceased to exist during the Tertiary owing to the AlpineHimalayan orogenesis. Since that time remnants of the original Tethys, such as the Mediterranean and Caribbean basins, have had their separate, modern geological history. In paleontology the use of the term "Tethys" is restricted to the endemic fauna of that sea which changed its character after the dismemberment of the Tethys Sea. In geology, therefore, the term refers to geographic patterns in the past, whereas in zoogeography it refers to actual distributions. When the term is applied to modern organisms one must take into account that the evolutionary history of these organisms continued after the existence of the original Tethys. Therefore, an unequivocal correlation between distributional data of recent organisms with Tethyan patterns of distribution and certain geological features of Tethyan origin cannot be expected. For example, the physiography of modern drainage basins may have had a strong impact on the distribution of stygobionts. However, the development of these basins is superposed on previous paleogeographic entities.

All members of Pseudoniphargus and those of its sister group Parapseudoniphargus are stygo- 
bionts. The second outgroup, Allomelita, is ecologically intermediate between marinebenthic, and littoral-interstitial conditions. Therefore, the progenitor of Pseudoniphargus may have been an inhabitant of shallow marine or littoral groundwaters. This probably thalassostygobiont progenitor presumably had only limited, active dispersal capabilities on account of the general characteristics of stygobiont amphipods (limited progenies and a lack of distributional life-phases). It was conceivably a sedentary species of littoral stygohabitats, unable to cross over open stretches of deep water and to compete with marine species. That the thalassostygobiont progenitor of the Pseudoniphargus group originated in the easternAtlantic part of the former Tethys sea is plausible since both Allomelita and Parapseudoniphargus have an eastern-Atlantic distribution (Stock, 1984; Notenboom, 1988a).

The actual distribution of Pseudoniphargus can be understood by a combination of (1) migration of the thalassostygobiont ancestor into the marine shallow water or littoral environment through vicariance and short-range dispersal, and (2) colonization of brackish and fresh inland groundwaters by local dispersal or by passively isolated populations remaining after the withdrawal of the sea ("Regression Model"; Stock, 1977). Taking this for granted, one may assume that the disjunct distributional areas of Pseudoniphargus have been interconnected by shallow, epicontinental seas in space and time, the areas exclusively populated through local dispersals excepted. However, the colonization of inland groundwaters by Pseudoniphargus cannot be explained by assuming successive local waves of dispersals as the major mechanism, since its continental distribution clearly coincides with areas flooded by epicontinental Tertiary seas. The distribution of the ancestral Pseudoniphargus in shallow marine, interstitial and crevicular habitats follows a mechanism very similar to that proposed for the marine interstitial sand fauna (Sterrer, 1973), and for anthurid isopods (Wägele, 1985).
The distribution of Pseudoniphargus is frequently called amphi-Atlantic (Sket \& Iliffe, 1980; Hart et al., 1985; Manning et al., 1986; Stock et al., 1986; Stock, 1988, in press) in view of its occurrence in the Iberian Peninsula, the western peri-Mediterranean region, and Atlantic islands (Bermuda, The Azores, Madeira, The Canaries). However, the genus has not been recorded from continental America nor from the Caribbean and evidently only the records from the isolated island of Bermuda renders the distribution of Pseudoniphargus allegedly amphi-Atlantic. Amphi-Atlantic distribution patterns of thalassoid stygobionts are explained by posing that the ancestor of the group was distributed along the shores of the Tethys before the opening of the Atlantic ocean in the Mesozoic, and that taxa became isolated by vicariance through Mesozoic plate tectonics (Sterrer, 1973; Iliffe et al., 1984; Wägele, 1985; Wilkens et al., 1986; Rondé-Broekhuizen \& Stock, 1987). Since Pseudoniphargus neither occurs in the Caribbean nor in North America, and since Bermuda is supposed to have never been a part of the North-American land mass (Manning et al., 1986), it is not plausible that the ancestral Pseudoniphargus was wide-spread before the opening of the Atlantic ocean or at the time the nascent Atlantic was still shallow. The opening of the Atlantic started between 165 and $140 \mathrm{mY}$ ago, shallow-water contacts between Iberia, Europe, and North America persisting until about $110 \mathrm{mY}$ ago (Sclater et al., 1977). In contradistinction, Manning et al. (1986) supposed that a limnic ancestor of Pseudoniphargus invaded the subterranean waters of the Atlantic islands in the Middle Jurassic (170 mY ago) long before the Atlantic ocean opened and the islands drifted away from the Mid-Atlantic ridge. In their hypothesis connections are presumed to have existed between limnic or mixohaline, insular and continental stygohabitats.

Explanations of the Atlantic distribution of Pseudoniphargus focus on the question how representatives can occur in fresh- to saltwater habitats on islands at present surrounded by 
deep ocean waters. Anoxia events in the Atlantic during the Middle Tertiary (Fischer \& Arthur, 1977) renders a Late Tertiary or more recent deep-sea origin of Pseudoniphargus unlikely (Stock, 1986b). The Atlantic islands in which Pseudoniphargus occurs share an origin from the Mid-Atlantic Ridge (Mitchell-Thomé, 1976). The Azores, Madeira, and the western Canaries drifted to the east, and only Bermuda drifted westward with the North-American plate. The presence of Pseudoniphargus and other stygobionts, such as Curassanthura, Procaris, and Typhlatya, in groundwaters of Atlantic oceanic islands is explained by supposing shallow-water contacts in the Mesozoic between the islands or their submarine, but shallow, primordials and the epicontinental Tethys sea. In a later phase of their geological history the islands, with their original stygofaunas, became isolated by deep waters (Iliffe et al., 1983; Manning et al., 1986; Stock, 1988, in press). However, current geological opinions, according to which the islands have been built up from the deep sea by volcanic activity, do not support the idea of an existence of long-standing, shallow-water stygohabitats before these islands started their subaerial phase (Mitchell-Thomé, 1976; Schmincke, 1976; Iliffe et al., 1983). Thus, there seems to be a profound discrepancy between the geological and zoogeographical data concerning the Atlantic islands.

After the Atlantic islands arose above sea level (subaerial phase), inland groundwater habitats with low salinities developed. The occurrence of Pseudoniphargus in these low salinity habitats might be explained by local dispersal of the thalassostygobiont ancestor. Such a mechanism is supported by the findings of Stock (1988) in the western Canary islands. His data suggest that Pseudoniphargus species occur in habitats with the lowest salinities in the oldest island (Tenerife), and at sites with the highest salinity in the youngest (El Hierro). All records of Pseudoniphargus from the Canaries are from low altitudes near the sea. In case flocks of inland species of Pseudoniphargus may be found in an Atlantic island, and presupposing that only one single thalassostygobiont ancestor existed, one may accept that these species must have had a monophyletic origin. In the case of the two Bermudian species, the monophyly has been proved beyond reasonable doubt. However, the phylogenetic relationships among the recently described cluster of species from the western Canary islands, which could not be included in the present study, have not yet been resolved (Stock, 1988).

On the Iberian Peninsula Pseudoniphargus has a disjunct distribution with two large clusters of endemic species limited to Cantabria in the north and the Betics in the south (fig. 22b). Monophyletic groups and species of equivocal affinity have in Cantabria an east-west orientated sequence of adjacent distributions, whereas in the Betics the distribution pattern is complex and intermingled. Within the range of the $P$. branchiatus group, which covers the entire Betic Cordillera, there are several species of uncertain affinity. In addition, the ingroup analysis showed that the North-Spanish species in general possess a relatively large amount of plesiomorphous features (plesiomorphic species sensu Saether, 1983). The South-Spanish species on the other hand are the most apomorphic (sensu Saether, 1983) of the genus. The two distinct, phylogenetic and distributional patterns of Pseudoniphargus in northern and in southern Spain may be attributed to the different geological histories of the two regions.

Structurally, the Cantabrian mountain ridge forms the northern part of the Hercynian Iberian Massif. Cantabria differentiated from the remaining Iberian Massif by extensive marine deposits of Late-Paleozoic and Mesozoic age, and by a complex orogenic history (Ager, 1980). The latest marine influences in the region date from the MesozoicCenozoic boundary. The retreat of the sea is connected with the closing of the SouthPyrenean trough and the emergence of the Pyrenees (Mattauer \& Henry, 1974; Plaziat, 1981).

Plaziat (1981) gives paleogeographic reconstructions of the wider peri-Pyrenean region (Asturias-Languedoc). According to this 

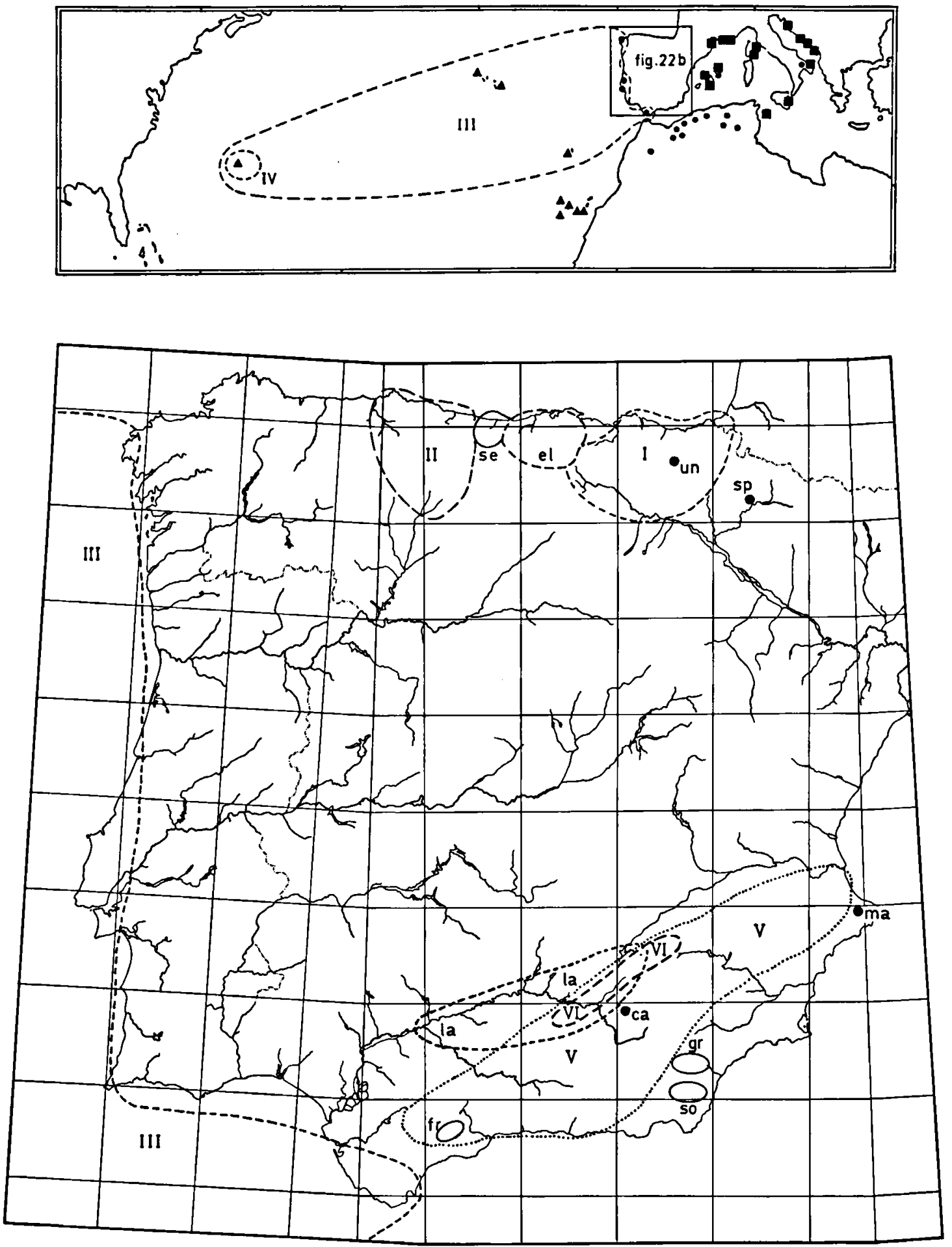

Figs. 22a \& b. Geographic distribution of monophyletic groups and ungrouped species of Pseudoniphargus. I, BurgoVasconia group; II, Cantabrian group; III, Lusitanian-Atlantic group; IV, Bermuda subgroup; V, P. branchiatus group; VI, $P$. vomeratus-illustris subgroup. Squares: marine species (cf. $P$. adriaticus); dots: inland species; triangles: species of oceanic islands. Abbreviations used for ungrouped Iberian species of Pseudoniphargus ca: cazorlae; el: elongatus; fr: fragilis; gr: gracilis; la: latipes; ma: margalefi; se: semielongatus; sp: spiniferus; so: sorbasiensis; un: unisexualis. 
author, the North-Spanish margin of the Iberian Massif was flooded by the sea in the Santonian (Late Cretaceous) (fig. 23). All known Pseudoniphargus localities lay at that time below sea level. North and south of the Pyrenees there were parallel troughs which deepened and widened towards the Gulf of Biscay. To the south the shallow sea extended without linking up with the marine Betic domain. In the Campanian/Maastrichtian (Late Cretaceous) the sea retreated definitely from Asturias. At the beginning of the Tertiary, Cantabria was marine east of Santander, and terrestrial westwards of that town. The deep Gulf of Biscay still extended into a part of Basque Country. Subsequently, during the Thanetian transgressive phase the coastline shifted to the west and south, but Asturias remained continental. During the following period that ended after the Biarritzian (MiddleLate Eocene) (fig. 24), the coastline did not change dramatically. During the Pyrenean phase in the Priabonian (Late Eocene) important regressions took place and in northern Spain the seashore obtained more or less its present position. Neotectonics and erosion

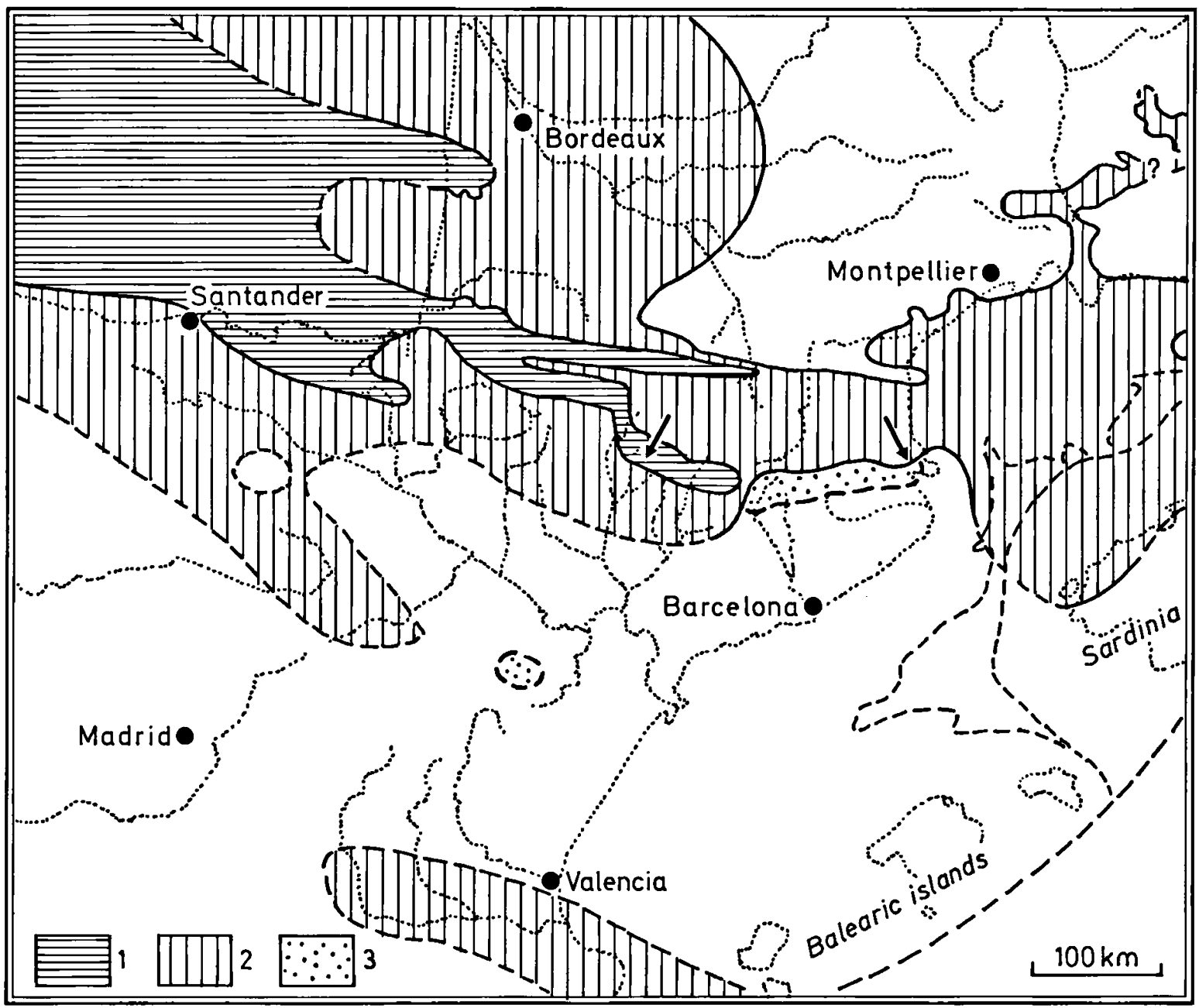

Fig. 23. Paleogeography of the peri-Pyrenean region during the Santonian (ca. $80 \mathrm{mY}$ ago), superimposed on the actual topography (palinspastic reconstruction): 1 , basinal facies; 2 , platform facies; 3 , permanent continental sedimentation; arrows indicate tectonic displacement enabling reconstruction of the original position. Slightly modified after Plaziat (1981). 
created the modern topography and drainage basins of the region. The reconstruction by Plaziat (1981) shows that Asturias, including the range of the plesiomorphic Cantabrian group of Pseudoniphargus, came to lie permanently above sea level during the Late Cretaceous. Moreover, the Basque Country in the eastern part of the Pseudoniphargus range lay in the centre of the basin from which the sea definitely retreated in the Late Eocene. The remaining North-Spanish localities of Pseudoniphargus were flooded by shallow marine water, the withdrawal of these waters taking place in a north-east direction during the Eocene.

The Betic Cordillera is structurally much younger than the Hercynean continental mass to which it abuts in the south. The area has a very complex Cretaceous to Late Tertiary tectonic and sedimentation history and is built up by plate fragments. Marine trans- and regressions took place irregularly but frequently in interior and in marginal basins of the whole area till the end of the Miocene (Messinian). During several phases of its history the Betics

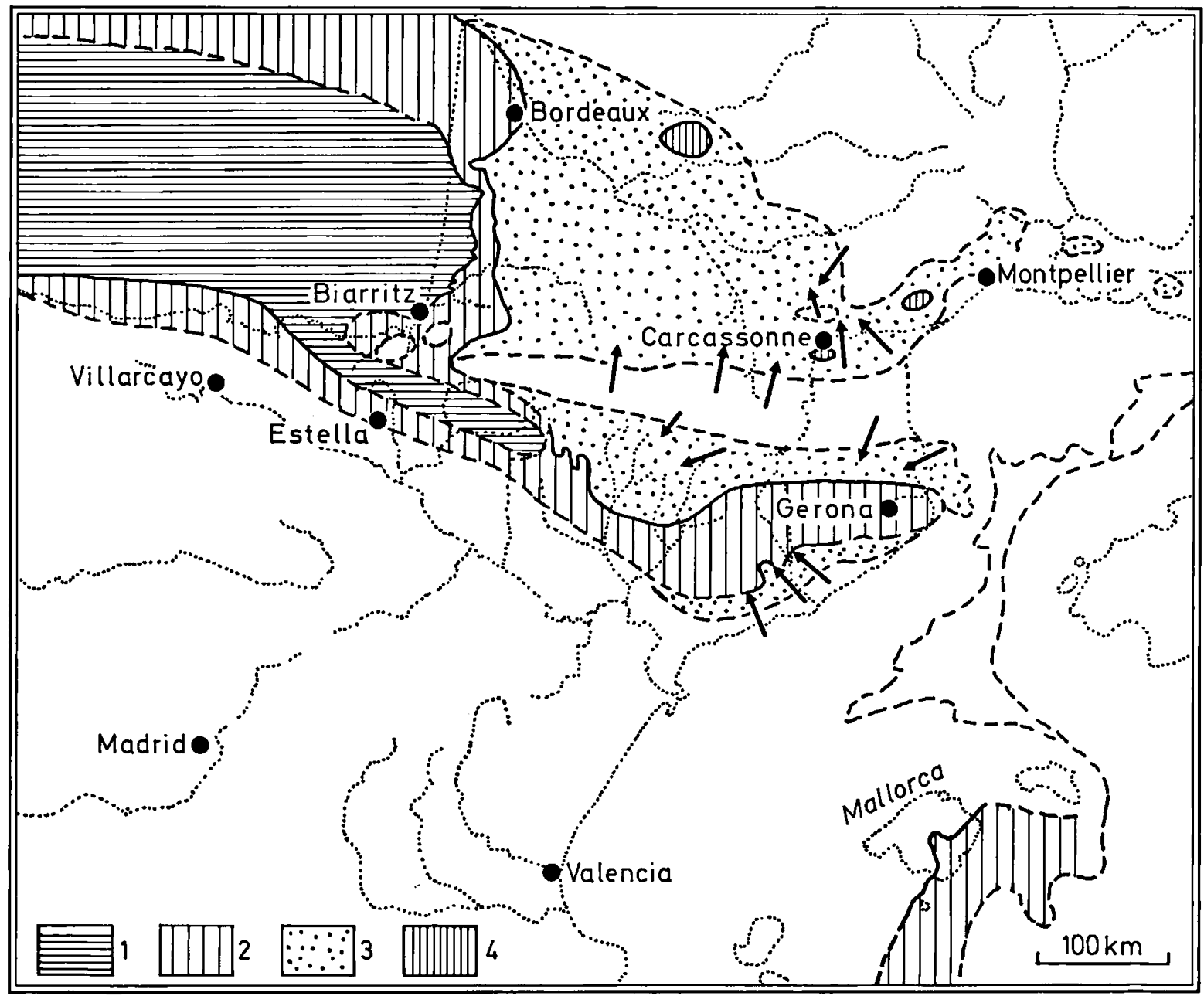

Fig. 24. Paleogeography of the peri-Pyrenean region during the Biarritzian s.1. (ca. $42 \mathrm{mY}$ ago), superimposed on the actual topography (palinspastic reconstruction): 1 , basinal facies; 2 , platform facies; 3 , permanent continental sedimentation; 4, lacustrine facies; arrows indicate terrigenous supply. Slightly modified after Plaziat (1981). 
must have resembled an archipelago (Roep, pers. comm.). The supposed position of islands, and marginal and internal basins during the transgressive phase of the Messinian is shown in fig. 25. The salinity crisis and the desiccation of the Mediterranean took place at the end of the Messinian. After the Messinian, during the Pliocene, an important Atlantic transgression invaded the entire Guadalquivir basin. The Mediterranean at that time slightly transgressed into some of the marginal basins. A wide-spread transgressive phase in the Betics has been during the Tortonian (Late Miocene, pre-Messinian). Many localities of Pseudoniphargus that do not lie near the coast or in the Guadalquivir basin, are situated in areas that probably underwent the latest marine influences during the Tortonian (viz. $P$. sorbasiensis, gracilis, nevadensis, granadensis, grandis (partim), and stocki).

Cantabria and the Betics differ in many respects, two of which are probably relevant to the biogeography of Pseudoniphargus: (1) the latest marine influences in Cantabria are of much older date than those in the Betics, so that Pseudoniphargus must have invaded Cantabria in an earlier phase and the Betics in a later phase of its evolutionary history, so the occurrence of relatively apomorphic forms in the Betics might also be attributable to this situation as suggested by Hennig's "progression rule" (Hennig, 1966); and (2) in Cantabria the sea retreated finally in an approximately north-east direction, while the retreat of the sea in the Betics was more intricate and diachronous from numerous marginal and internal basins. These facts could have some bearing upon the different distributional patterns of Pseudoniphargus encountered in Cantabria and the Betics. The Guadalquivir basin, which underwent a Pliocene Atlantic influence, possesses a rather large number of endemic malacostracan groundwater crustaceans, including species of Pseudoniphargus, Metahadzia, Salentinella,

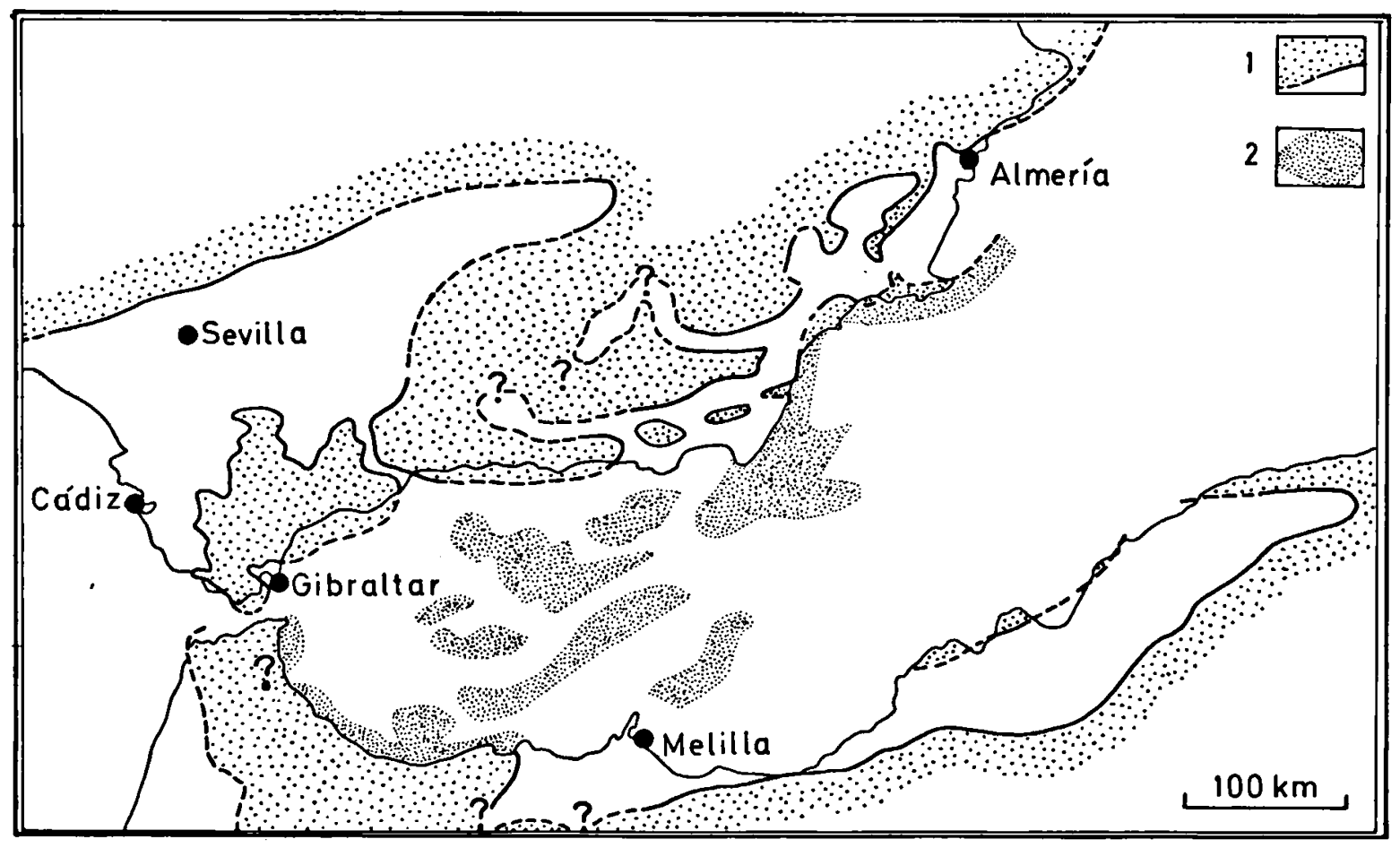

Fig. 25. Paleogeography of the Betic domain during the maximum extension of the sea in the Messinian (ca. $6 \mathrm{mY}$ ago), superimposed on the actual topography: 1 , coastline, dotted areas indicate land masses; 2 , possible extension of emerged lands in the Alboran sea. Slightly modified after Montenat (1977). 
Stenasellus and Proasellus, and the genera Monodella and Parapseudoniphargus that are not found elsewhere in Iberia (Notenboom, 1988a). However, there is no evidence that the Pseudoniphargus species from the Guadalquivir area have a monophyletic origin.

The northern belt of the western Mediterranean is populated by the only marine/polyhaline species of the genus, $P$. adriaticus. It is rather apomorphic and probably belongs to the $P$. branchiatus group. $P$. adriaticus is the only wide-spread species, but conceivably the several distant populations are to some extent epiphenotypically differentiated. Presumably $P$. adriaticus is a rather young expanding and euryoecious species that penetrated into the Mediterranean basin in a later stage of the history of the genus. That the species is only known from the western Mediterranean basin, the Adriatic included, and not from the eastern basin suggests that the settlement of $P$. adriaticus in the Mediterranean is of a rather recent and probably post-Messinian date.

In the western peri-Mediterranean region, limnic Pseudoniphargus species are absent from nearly all areas where the limnic stygobiont genus Niphargus is well established (southern France, Italy, Yugoslavia). In areas not populated by Niphargus (Iberia, except two small disjunct areas on both edges of the Pyrenees, and northern Africa), limnic Pseudoniphargus species are abundant in regions where Tertiary marine influences have been recorded. From these facts Stock (1980a) deduced that the distribution of limnic Pseudoniphargus taxa can be explained by (1) the incidence of marine regressions during the Tertiary ("Regression Model"), and (2) the lack of competition with older limnic stygobiont genera, such as Niphargus. However, the universal applicability of these two arguments may be queried. In a small area lying to the west of the Pyrenees, Pseudoniphargus frequently occurs sympatrically with Niphargus (Notenboom, 1986). Furthermore the central-eastern part of Spain (Levante-Castillón) is completely devoid of Pseudoniphargus. Although during the Tertiary that area was probably not subjected to important marine influences (Plaziat, 1981; Canerot, 1974), large-scale paleogeographic maps such as given by Biju-Duval et al. (1977) and Dercourt et al. (1985) clearly show marine transgressions during the Tortonian, which transgressions did not penetrate far inland and remained confined to areas near the coast. Although Pseudoniphargus has frequently been recorded from parts of the Betics and northern Africa flooded by the pre-Messinian Mediterranean Sea, it has not been found in Levante despite intensive sampling in the area. Apparently, neither a competition with older, limnic stygobionts nor Tertiary marine influences are consistently the only key factors explaining the distribution of Pseudoniphargus in inland groundwaters of the western Mediterranean.

\section{ACKNOWLEDGEMENTS}

I am most grateful to Dr. George D. F. Wilson, Tim G. Brom, and Dr. Hans Duffels for their improving comments on different drafts of the manuscript, and also to Professor Dr. Jan H. Stock for his perusal of successive drafts. I highly appreciate the valuable discussions about the geology of Spain, in particular of the Betics, with Dr. Thomas Roep, and about phylogenetic methodology with colleagues during our "Brainstroom" sessions. I am indebted to Professor Dr. A. D. J. Meeuse who kindly improved the English of this paper and to Dr. Xavier Bellés for translating the abstract into Spanish.

Dirk Platvoet and Young Won Jo are thanked for their technical assistance during the SEM examinations of the animals, Mr. J. Zaagman for his help in preparing the figures, and Mr. L. A. van der Laan for the printings of SEM photographs.

I am indebted to Dr. Willem Ellis and to Dr. Rino Zandee for providing the opportunity and their assistance during the analyses of the data sets with their computer programs in the initial phase of this study. Theodore Hijermans is thanked for executing preliminary runs with PHYLIP.

This paper is part of a $\mathrm{Ph}$. D. thesis project supported by the Foundation for Fundamental Biological Research (BION), which is subsidized by the Netherlands Organization for Scientific Research (NWO). 


\section{REFERENCES}

Ager, D. V., 1980. The geology of Europe: i-xix, 1-535 (McGraw-Hill, London etc.).

Archie, J. W., 1985. Methods for coding variable morphological features for numerical taxonomic analysis. Syst. Zool., 34 (3): 326-345.

Arnold, E. N., 1981. Estimating phylogenies at low taxonomic levels. Z. zool. Syst. Evolut.-forsch., 19: 1-35.

Barnard, J. L., 1976. Affinities of Paraniphargus lelouparum Monod, a blind anchialine amphipod (Crustacea) from the Galapagos Islands. Proc. biol. Soc. Wash., 89 (36): 421-432.

-, 1977 . The cavernicolous fauna of Hawaiian lava tubes, 9. Amphipoda (Crustacea) from brackish lava ponds on Hawaii and Maui. Pacific Insects, 17 (2/3): 267-299.

- - 1979. Littoral grammaridean Amphipoda from the Gulf of California and the Galapagos Islands. Smithson. Contr. Zool., 271: 1-149.

Barnard, J. L. \& C. M. Barnard, 1983. Freshwater Amphipoda of the world, I. Evolutionary patterns; II. Handbook and bibliography: 1-830 (Hayfield Associates, Mt. Vernon, Virginia).

Barnard, J. L. \& G. S. Karaman, 1980. Classification of gammarid Amphipoda. Crustaceana, Suppl. 6: 5-16.

BArR, TH. C., 1968. Cave ecology and the evolution of troglobites. In: Th. Dobzhanski, M. K. Неcht W. C. Steere eds., Evolutionary biology, 2: 35-102 (North Holland Publ. Comp., Amsterdam).

Biju-Duval, B., J. Dercourt X. Le Pichon, 1977. From the Tethys Ocean to the Mediterranean seas: a plate tectonic model of the evolution of the western Alpine system. In: B. Biju-Duval \& L. Montadert eds., Int. Symp. structural history of the Mediterranean basins, Split: 143-164 (Éditions Technip, Paris).

Bou, CL., 1975. Recherches sur la faune souterraine de Grèce. Biologia gallo-hell., 6 (1): 101-115.

Bousfield, E. L., 1970. Terrestrial and aquatic amphipod Crustacea from Rennell Island. The Natural History of Rennell Island, British Solomon Islands, 6: 155-168.

- - 1971. Amphipoda of the Bismarck Archipelago and adjacent Indo-Pacific islands (Crustacea). Steenstrupia, 23 (1): 255-293.

-, 1973. Shallow-water gammaridean Amphipoda of New England: 1-312 (Cornell University Press, Ithaca \& London).

- - 1977. A new look at the systematics of gammaroidean amphipods of the world. Crustaceana, Suppl. 4: 282-316.

- -, 1982. Amphipoda. In: S. P. PARker ed., Synopsis and classification of living organisms, 2: 241-285 (McGraw-Hill, New York).
- , 1983. An updated phyletic classification and palaeohistory of the Amphipoda. In: F. S. Schram ed., Crustacean phylogeny. Crustacean Issues, 1: 257-277 (A. A. Balkema, Rotterdam/Boston).

- , 1985. Ordered character states as a basis for phyletic classification within the Amphipoda. VIth int. Colloquium on Amphipod Crustaceans, June 28-July 3, 1985, Ambleteuse, France (unpublished lecture and abstract).

Boutin, Cl. N. Coineau, 1988. Pseudoniphargus maroccanus n. sp. (subterranean amphipod), the first representative of the genus in Morocco. Phylogenetic relationships and palaeobiogeography. Crustaceana, Suppl. 13: 1-19.

Boutin, Cl. \& M. Messouli, 1988. Longipodacrangonyx maroccanus, n. gen., n. sp., nouveau représentant du groupe Metacrangonyx dans les eaux souterraines du Maroc. Crustaceana, Suppl. 13: 256-271.

Camin, J. H. R. R. Sokal, 1965. A method for deducing branching sequences in phylogeny. Evolution, 19: $311-326$.

Canerot, J., 1974. Recherches géologiques aux confines des chaînes ibérique et catalane (Espagne): 1-520 (Thèse Sciences, Toulouse; Enadimsa, Trabajos de Tesis).

Caruso, D. G. Costa, 1978. Ricerche faunistiche ed ecologiche nelle grotte di Sicilia, VII. Fauna cavernicola di Sicilia (Catalogo ragionato). Animalia, 5 (1/3): 423-513.

Chevreux, E., 1901. Amphipodes des eaux souterraines de France et d'Algérie, V. Pseudoniphargus africanus nov. gen. et spec. Bull. Soc. zool. Fr., 26: 211-216.

Chilton, C., 1921. Niphargus philippensis, a new species of amphipod from the underground waters of the Philippine Islands. Philipp. J. Sci., 17 (5): 515-523.

Coineau, N., 1984. Quelques aspects de l'adaptation des Crustacés Isopodes, Amphipodes et Syncarides à la vie dans le milieu interstitiel. Mém. Biospéol., 11: 7-15.

Conlan, K. E., 1988. Phenetic and cladistic methods applied to a small genus (Corophioidea: Ischyroceridae: Microjassa) and a larger outgroup. Crustaceana, Suppl. 13: 143-166.

Culver, D. C., 1982. Cave life. Evolution and ecology: 1-189 (Harvard University Press, Cambridge, Mass. etc.).

Culver, D. C. D. W. Fong, 1986. Why all cave animals look alike. Stygologia, 2 (3): 208-216.

DAHL, E., 1976. Structural plans as functional models exemplified by the Crustacea Malacostraca. Zoologica Scr., 5: 163-166.

Danielopol, D., 1980. An essay to assess the age of the freshwater interstitial ostracods of Europe. Bijdr. Dierk., 50 (2): 243-291.

Dercourt, J. et al., 1985. Présentation de 9 cartes paléogéographiques au 1/20.000.000ème s'étendant 
de l'Atlantique au Pamir pour la période du Lias à l'Actuel. Bull. Soc. géol. Fr., (8) 1 (5): 637-652; 10 cartes en couleur hors texte.

Eck, R. V. \& M. O. DAYнoff, 1966. Atlas of protein sequence and structure (National Biomedical Research Foundation, Silver Springs, Maryland).

Ellis, W. N., 1987. Tree tools version 2.2; a program for the Macintosh computer for generation of Wagner character state networks (available from the author, c/o Institute of Taxonomic Zoology, Entomology Department, Plantage Middenlaan 64, $1018 \mathrm{DH}$ Amsterdam).

Felsenstein, J., 1981. A likelihood approach to character weighting and what it tells us about parsimony and compatibility. Biol. J. Linn. Soc., 16: 183-196.

-, 1982 . Numerical methods for inferring evolutionary trees. Quart. Rev. Biol., 57 (4): 379-404.

- , 1984. The statistical approach to inferring evolutionary trees and what it tells us about parsimony and compatibility. In: Th. Duncan \& T. F. Stuessy eds., Cladistics: perspectives on the reconstruction of evolutionary history: 169-191 (Columbia University Press, New York).

-_, 1985. Confidence limits on phylogenies: an approach using the bootstrap. Evolution, 39 (4): 783-791.

- - 1987. PHYLIP (Phylogeny Inference Package) version 3.0 manual (available from the author, c/o University of Washington, Department of Genetics SK-50, Seattle, Washington 98195, U.S.A.).

Fischer, A. G. M. A. Arthur, 1977. Secular variations in the pelagic realm. Soc. econ. Paleont. Mineral. spec. Publ., 25: 19-50.

Gauthier, H., 1936. Eriopisa seurati, nouvel Amphipode du Sud-tunisien. Bull. Soc. Hist. nat. Afr. Nord, 27: 133-143.

GiberT, J., 1986. Écologie d'un système karstique Jurassien. Hydrogéologie, dérive animale, transits de matières, dynamique de la population de Niphargus (Crustacé Amphipode). Mém. Biospéol., 13: 1-376.

Ginet, R., 1960. Écologie, éthologie et biologie de Niphargus (Amphipodes Gammaridés hypogés). Annls. Spéléol., 15 (1/2): 1-254.

Ginet, R. V. Decou, 1977. Initiation à la biologie et à l'écologie souterraines: 1-345 (J.-P. Delarge, Paris).

Gourbault, N. \& F. Lescher-Moutoué, 1979. Faune des eaux souterraines de Majorque. Endins, 5-6: 43-54.

Griffiths, C. L., 1974. The Gammaridea and Caprellidae of south west Africa. Ann. S. Afr. Mus., 62 (6): 169-208.

Halcrow, K. E. L. Bousfield, 1987. Scanning electron microscopy of surface microstructures of some gammaridean amphipod crustaceans. J. crust. Biol., 7 (2): 274-287.

Hart, C. W. Jr., R. B. Manning \& T. M. Illffe, 1985. The fauna of Atlantic marine caves: evidence of dispersal by sea floor spreading while maintaining ties to deep water. Proc. biol. Soc. Wash., 98 (1): 288-292.

Hartnole, R. G., 1985. Growth, sexual maturity and reproductive output. In: A. W. WENNER ed., Factors in adult growth. Crustacean Issues, 3: 101-128 (A. A. Balkema, Rotterdam/Boston).

Hennic, W., 1966. Phylogenetic systematics: 1-163 (Univ. of Illinois Press, Urbana).

Henry, J.-P., 1976. Recherches sur les Asellides hypogés de la lignée cavaticus (Crustacea, Isopoda, Asellota): 1-270 (Thèse Biol. Univ. Dijon, $N^{\circ}$ dépôt CNRS: $A$. O. 12143).

Holsinger, J. R., 1986. Zoogeographic patterns of North American subterranean amphipod crustaceans. In: R. H. GoRe \& K. L. Heck eds., Crustacean biogeography. Crustacean Issues, 4: 85-106 (A. A. Balkema, Rotterdam/Boston).

Holsinger, J. R. \& D. C. Culver, 1988. The invertebrate cave fauna of Virginia and a part of eastern Tennessee: zoogeography and ecology. Brimleyana, 14: 1-162.

Iliffe, T. M., C. W. Hart JR. \& R. B. Manning, 1983. Biogeography and the caves of Bermuda. Nature, 302: 141-142.

Iliffe, T. M., H. Wilkens, J. Parzefall \& D. Williams, 1984. Marine lava cave fauna: composition, biogeography, and origins. Science, 225: 309-311.

Johnson, R., 1982. Parsimony principles in phylogenetic systematics: a critical re-appraisal. Evol. Theory, 6: 79-90.

Karaman, G. S., 1978a. Revision of the genus Pseudoniphargus Chevreux 1901 (fam. Gammaridae). Boll. Mus. civ. Stor. nat. Verona, 5: 239-258.

from the Mediterranean Sea, M. bulla n. sp. and M. valesi S. Kar. 1955. Boll. Mus. civ. Stor. nat. Verona, 5: 221-237.

-, 1981 . Redescription of Melita planaterga Kunkel 1910 from Bermuda islands with revision of genera Melita Leach and Abludomelita n. gen. Poljoprivreda i Sumarstvo, 27 (1): 29-50.

-_, 1982. Gammaridae. In: S. Rufro ed., The Amphipoda of the Mediterranean. Mém. Inst. océanogr. Monaco, 13: 245-364.

,$-- 1984 a$. Revision of the Eriopisa-complex of genera (Gammaridea). Poljoprivreda i Sumarstvo, 30 (4): 39-72.

- , 1984b. Quadrus vagabundus, new genus and species, and revision of genus Eriopisella Chevr. (Gammaridea). Studia Marina, 15-16: 131-148.

Karaman, G. S. \& J. L. Barnard, 1979. Classificatory revisions in gammaridean Amphipoda (Crustacea), part 1. Proc. biol. Soc. Wash., 92: 106-165.

KLuge, A. G., 1984. The relevance of parsimony to phylogenetic inference. In: $T_{H}$. Duncan T. F. Stuessy eds., Cladistics: perspectives on the 
reconstruction of evolutionary history: 24-38 (Columbia University Press, New York).

Kluge, A. G. * J. S. FArris, 1969. Quantitative phyletics and the evolution of anurans. Syst. Zool., 18: 1-32.

Kluge, A. G. \&. E. Strauss, 1985. Ontogeny and systematics. Ann. Rev. Ecol. Syst., 16: 247-268.

Ledoyer, M., 1978. Amphipodes Gammariens (Crustacea) des biotopes cavitaires organogenèse récifaux de l'île Maurice (Océan Indien). Mauritius Inst. Bull., 8 (3): 197-332.

- - 1982. Crustacés Amphipodes Gammariens, familles des Acanthonotozomatidae à Gammaridae. Faune de Madagascar, 59 (1): 1-598.

Le Quesne, W. J., 1969. A method of selection of characters in numerical taxonomy. Syst. Zool., 18: 201-205.

Lincoln, R. J., 1979. British marine amphipoda: Gammaridea: 1-658 (British Museum Natural History, London).

- - 1984. The amphipod calceolus as an indicator of phyletic affinity. Communication Amphipod Workshop, Ottawa.

Lincoln, R. J. \& D. E. Hurley, 1981. The calceolus, a sensory structure of gammaridean amphipods (Amphipoda: Gammaridea). Bull. Br. Mus. nat. Hist. (Zool.), 40 (4): 103-116.

Maddison, W. P., M. J. Donoghue \& D. R. Maddison, 1984. Outgroup analysis and parsimony. Syst. Zool., 33 (1): 83-103.

Magniez, G., 1976. Remarques sur la biologie et l'écologie de Stenasellus virei Dollfus (Crustacea Isopoda Asellota des eaux souterraines). Int. J. Speleol., 8: 135-140.

- - 1978. Précopulation et vie souterraine chez quelques Péracarides (Crustacea Malacostraca). Archs. Zool, exp. gén., 119: 471-478.

Manning, R. B., C. W. Hart JR. T. M. Iliffe, 1986. Mesozoic relicts in marine caves of Bermuda. Stygologia, 2 (1/2): 156-166.

Margalef, R., 1970. Anfípodos recolectados en aguas subterráneas ibéricas. Speleon, 17: 63-65.

Mattauer, M. * J. Henry, 1974. Pyrenees. In: A. M. Spencer ed., Mesozoic-Cenozoic orogenic belts. Data for orogenic studies. Geol. Soc., Spec. Publ., 4: 3-20 (The Geological Society, London).

MAYr, E., 1982. Processes of speciation in animals. In: C. Barigozzı ed., Mechanisms of speciation: 1-19 (Liss, New York).

Meacham, C. A. \& G. F. Estabrook, 1985. Compatibility methods in systematics. Ann. Rev. Ecol. Syst., 16: 431-446.

Mickevich, M. F., 1982. Transformation series analysis. Syst. Zool., 31 (4): 461-478.

Mickevich, M. F. M. S. Johnson, 1976. Congruence between morphological and allozyme data in evolutionary inference and character evolution. Syst. Zool., 25: 260-270.
Mitchell-Thomé, R. C., 1976. Geology of the Middle Atlantic islands. Beitr. reg. Geol. Erde, 12: i-ix, 1382 (Bornträger, Berlin/Stuttgart).

McKinney, L. D., R. D. Kalke \& J. S. Holland, 1978. New species of amphipods from the western Gulf of Mexico. Contr. mar. Sci., 21: 133-159.

Monon, Th., 1938. Sur une localité nouvelle d'Eriopisa seurati H. Gauthier, 1936. Bull. Soc. zool. Fr., 63: 244-247.

- 1970 . Sur quelques Crustacés Malacostracés des Iles Galapagos récoltés par N. et J. Leleup (19641965). Mission zool. belge aux îles Galapagos et en Ecuador (N. et J. Leleup, 1964-1965), 2: 11-53.

Montenat, $\mathrm{CH}_{\text {., }}$ 1977. Vue d'ensemble sur le Messinien du domain Bétique. Messinian Seminar no. 3. Málaga, 26 / 27 September 1977. Abstracts of papers. Project no. 96, Messinian correlation: 40-41 (Universidades de Málaga y Granada).

Notenвoоm, J., 1986. The species of the genus Pseudoniphargus Chevreux, 1901 (Amphipoda) from northern Spain. Bijdr. Dierk., 56 (1): 75-122.

- , 1987a. Species of the genus Pseudoniphargus Chevreux, 1901 (Amphipoda) from the Betic Cordillera of southern Spain. Bijdr. Dierk., 57 (1): 87-150.

-, 1987b. Lusitanian species of the amphipod Pseudoniphargus Chevreux, 1901 with a key to all known Iberian species. Bijdr. Dierk., 57 (2): 191-206.

- - 1988a. Parapseudoniphargus baetis, new genus, new species, a stygobiont amphipod crustacean from the Guadalquivir River Basin (southern Spain), with phylogenetic implications. J. crust. Biol., 8 (1): 110-121.

-, 1988 b. Metahadzia uncispina, a new amphipod from phreatic groundwaters of the Guadalquivir river basin of southern Spain. Bijdr. Dierk., 58 (1): 79-87.

- $1988 \mathrm{c}$. Biogeographic observations on the genera of Iberian stygobiont Amphipoda. Crustaceana, Suppl. 13: $122-133$.

Notenboom, J. \& A. J. De Winter, 1986 . Dutch biological and speleological exploration in Algeria, 5 . Survey of the groundwater-stations investigated in 1981 and 1983: 1-20 (Biospeleologische Werkgroep van Speleo Nederland, Amsterdam).

Pimentel, R. A. \& R. Riggins, 1987. The nature of cladistic data. Cladistics, 3 (3): 201-209.

Plaziat, J-CL., 1981. Late Cretaceous to Late Eocene palaeogeographic evolution of southwest Europe. Palaeogeography, Palaeoclimatology, Palaeoecology, 36: 263-320.

Rondé-Broekhuizen, B. L. M. \& J. H. Stock, 1987. Stygofauna of the Canary Islands, 2: A new ingolfiellid (Crustacea, Amphipoda) with West Indian affinities from the Canary Islands. Arch. Hydrobiol., 110 (3): 441-450. 
Rouch, R. \& D. Danielopol, 1987. L'origine de la faune aquatique souterraine entre le paradigme du réfuge et la modèle de la colonisation active. Stygologia, 3 (4): 345-372.

Rufro, S., 1956. Études sur les Crustacés Amphipodes, XLVI. Psammogammarus pauliani n. g. n. sp. nouveau Gammaride des eaux interstitielles de l'Ile de la Réunion. Mém. Inst. scient. Madagascar, (A) 11: 89-95.

-, 1979 . Descrizione di due nuovi Anfipodi anoftalmi dell'Iran e del Madagascar (Phreatomelita paceae $\mathbf{n}$. gen. n. sp., Dussartiella madegassa n. gen. n. sp.). Boll. Mus. civ. Stor. nat. Verona, 6: 419-440.

- - 1982. Gli Anfipodi delle acque sotterranee italiane. Lav. Soc. ital. Biogeog., (N. S.) 7 “1978”: 139-169.

- - 1985. Nuovi anfipodi mesopsammici delle isole Andamane (Crust. Amphipoda). Boll. Mus. civ. Stor. nat. Verona, 10: 485-509.

Ruffo, S. \& U. Schiecke, 1975. Descrizione di Eriopisa gracilis n. sp. (Amphipoda, Gammaridae) delle coste di Malta e rediscrizione di E. coeca (S. Karaman, 1955) (= E. peresi M. Ledoyer, 1968). Boll. Mus. civ. Stor. nat. Verona, 2: 415-438.

SAEther, O. A., 1983. The canalized evolutionary potential: inconsistencies in phylogenetic reasoning. Syst. Zool., 32 (4): 343-359.

Schellenberg, A., 1931. Amphipoden der SundaExpeditionen Thienemann und Rensch. Arch. Hydrobiol., Suppl. 8 (1): 493-511.

Schmincke, H. U., 1976. The geology of the Canary Islands. In: G. Kunkel ed., Biogeography and ecology in the Canary Islands: 67-184 (Junk, The Hague).

Schram, F. R., 1986. Crustacea: 1-606 (Oxford University Press, New York).

Sclater, J. G., S. Hellinger \& C. Tapscott, 1977. The paleobathymetry of the Atlantic Ocean from the Jurassic to the Present. J. Geol., 85: 509-552.

SKET, B., 1986. Ecology of the mixohaline hypogean fauna along the Yugoslav coasts. Stygologia, 2 (4): 317-338.

Sket, B. \& T. M. Iliffe, 1980. Cave fauna of Bermuda. Int. Revue ges. Hydrobiol., 65 (6): 871-882.

Sober, E., 1985. A likelihood justification of parsimony. Cladistics, 1: 209-233.

Sokal, R. R., K. L. Ftala \& G. Hart, 1984. OTU stability and factors determining taxonomic stability: examples from the Caminalculus and the Leptopodomorpha. Syst. Zool., 33 (4): 387-407.

Sterrer, W., 1973. Plate tectonics as a mechanism for dispersal and speciation in interstitial sand fauna. Neth. J. Sea Res., 7: 200-222.

Stock, J. H., 1974. The systematics of certain PontoCaspian Gammaridae (Crustacea, Amphipoda). Mitt. hamb. zool. Mus. Inst., 70: 75-95.

- - 1977. The taxonomy and zoogeography of the hadziid Amphipoda with emphasis on the West Indian taxa. Stud. Fauna Curaçao, 55 (177): 1-130.
- , 1980a. Regression model evolution as exemplified by the genus Pseudoniphargus (Amphipoda). Bijdr. Dierk., 50 (1): 105-144.

- 1 , 1980b. A new cave amphipod (Crustacea) from Curaçao: Psammogammarus caesicolus n. sp. Bijdr. Dierk., 50 (2): 375-386.

- 1983. A new species of Psammogammarus (Crustacea, Amphipoda) from the Roques Archipelago, Venezuela. Bijdr. Dierk., 53 (1): 103-108.

-, 1984 . Observations morphologiques et écologiques sur une population intertidale de "Melita" pellucida Sars (Amphipoda) à Étretat (Seine-Maritime, France). Cah. Biol. mar., 25: 93-106.

-, 1985 . Stygobiont amphipod crustaceans of the hadzioid group from Haiti. Bijdr. Dierk., 55 (2): $331-426$.

- , 1986a. Amphipoda: Melitid grouping (Melitidae sensu Bousfield, 1973, emend.). In: L. Botosaneanu ed., Stygofauna mundi: 504-513 (E. J. Brill, Leiden).

-, $1986 \mathrm{~b}$. Deep sea origin of cave faunas: an unlikely supposition. Stygologia, 2 (1/2): 105-111.

-, 1988. The amphipod genus Pseudoniphargus (Crustacea) in the Canary Islands. Bijdr. Dierk., 58 (1): 47-78.

- , in press. Insular groundwater biotas in the (sub)tropical Atlantic - biogeographic synthesis. Accademia Nazionale dei Lincei (conference lecture Rome, May 1987).

Stock, J. H., J. R. Holsinger, B. Sket \& Th. M. IlIFFE, 1986. Two new species of Pseudoniphargus (Amphipoda), in Bermudian groundwaters. Zoologica Scr., 15 (3): 237-249.

Stock, J. H. \& H. Nijssen, 1965. Eriopisa longiramus n. sp., a new subterranean amphipod from a Red Sea island. Sea Fish. Res. St., Haifa, 38: 28-39.

Stock, J. H. \& D. Platvoet, 1981. Le genre Victoriopisa signalé pour la première fois en Atlantique Nord: description de V. atlantica nov. sp. de Mauritanie (Crustacea, Amphipoda). Bull. zoöl. Mus. Univ. Amsterdam, 8 (3): 21-30.

Stock, J. H. \& B. L. M. Rondé-Broekhuizen, 1986. A new species of Pygocrangonyx, an amphipod genus with African affinities, from Fuerteventura. Bijdr. Dierk., 56 (2): 247-266.

Stock, J. H. E. Sanchez, 1987. Psammogammarus initialis n. sp., a new mediolittoral interstitial amphipod crustacean from Tenerife. Stygologia, 3 (3): 264-277.

Tatrersal, W. M., 1925. Freshwater Amphipoda from the Andaman Isles. Rec. indian Mus., 25 (4): 241-247.

Turquin, M. J., 1984a. Un cas de transition démographique dans le milieu souterrain. Verh. int. Verein. Limnol., 22: 1751-1754.

--, 1984b. Age et croissance de Niphargus virei (Amphipode pérennant) dans le système karstique de 
Drom: méthodes d'estimation. Mém. Biospéol., 11: 37-49.

VAndel, A., 1965. Biospeleology. The biology of cavernicolous animals: 1-524 (Pergamon Press, Oxford).

Vaupel Klein, J. C. von, 1987. Phylogenetic analysis and its foundations. In: P. Hovenkamp gen. ed., Systematics and evolution: a matter of diversity: 159172 (Utrecht University, Utrecht).

WÄGELE, J.-W., 1985. On the tethyan origin of the stygobiont Anthuridea Curassanthura and Cyathura (Stygocyathura), with description of Curassanthura canariensis n. sp. from Lanzarote (Crustacea, Isopoda). Stygologia, 1 (3): 258-269.

Watrous, L. E. \& Q. D. WheEler, 1981. The out-group comparison method of character analysis. Syst. Zool., 30: 1-11.

Wiley, E. O., 1981. Phylogenetics. The theory and practice of phylogenetic systematics: 1-439 (John Wiley * Sons, New York).

Wilkens, H., J. Parzefall T. M. Iliffe, 1986. Origin and age of the marine stygofauna of Lanzarote, Canary Islands. Mitt. hamb. zool. Mus. Inst., 83: 223-230.

ZANDEE, M., 1987. A computing environment for cladistic analysis. Preliminaries of a user manual for CAFCA/PC. In: P. Hovenkamp gen. ed., Systematics and evolution: a matter of diversity: 111140 (Utrecht University, Utrecht).

Received: 30 June 1988 